This is the accepted version of the following article: Khater, M., De la Escosura, A. and Merkoçi, A. "Biosensors for plant pathogen detection" in Biosensors and bioelectronics (Ed. Elsevier), vol. 93 (2017), p. 72-86, which has been published in final form at 10.1016/j.bios.2016.09.091. ( ) 2017. This manuscript version is made available under the CC-BY-NC-ND 4.0 license http://creativecommons.org/licenses/by-nc-nd/4.0/

\title{
Biosensors for plant pathogen detection
}

\author{
Mohga Khater ${ }^{1,2}$, Alfredo de la Escosura-Muñiz ${ }^{1}$,Arben Merkoçi ${ }^{1,3 *}$
}

${ }^{1}$ Catalan Institute of Nanoscience and Nanotechnology (ICN2), CSIC and Barcelona Institute of Science and Technology, Campus UAB, 08193 Barcelona, Spain.

${ }^{2}$ On leave from Agricultural Research Center (ARC), Ministry of Agriculture and land reclamation, Giza, Egypt

${ }^{3}$ ICREA, Pg. Lluís Companys 23, 08010 Barcelona, Spain.

Phone number: +34937374604 ; Fax number: +34935868020

*E-mail: arben.merkoci@icn2.cat 


\section{ABSTRACT}

Infectious plant diseases are caused by pathogenic microorganisms such as fungi, bacteria, viruses, viroids, phytoplasma and nematodes. Worldwide, plant pathogen infections are among main factors limiting crop productivity and increasing economic losses. Plant pathogen detection is important as first step to manage a plant disease in greenhouses, field conditions and at the country boarders. Current immunological techniques used to detect pathogens in plant include enzymelinked immunosorbent assays (ELISA) and direct tissue blot immunoassays (DTBIA). DNA-based techniques such as polymerase chain reaction (PCR), real time PCR (RT-PCR) and dot blot hybridization have also been proposed for pathogen identification and detection. However these methodologies are time-consuming and require complex instruments, being not suitable for in-situ analysis. Consequently, there is strong interest for developing new biosensing systems for early detection of plant diseases with high sensitivity and specificity at the point-of-care. In this context, we revise here the recent advancement in the development of advantageous biosensing systems for plant pathogen detection based on both antibody and DNA receptors. The use of different nanomaterials such as nanochannels and metallic nanoparticles for the development of innovative and sensitive biosensing systems for the detection of pathogens (i.e. bacteria and viruses) at the point-of-care is also shown. Plastic and paper-based platforms have been used for this purpose, offering cheap and easy-to-use really integrated sensing systems for rapid on-site detection. Beside devices developed at research and development level a brief revision of commercially available kits is also included in this review.

\section{KEYWORDS}

Plant pathogen, bacteria, virus, biosensor, point-of-care, nanomaterial, antigen, DNA. 


\section{INTRODUCTION}

Plant pathogens are one of the causes for low agricultural productivity worldwide. Main reasons are new, old and emerging plant infectious diseases. Their rates of spread, incidence and severity have become a significant threat to the sustainability of world food supply (Pimentel et al., 2005; Oerke, 2006; Roberts et al., 2006; Savary et al., 2012). Despite the lack of sufficient information for the economic losses, it was reported from plant disease loss estimates in U.S state of Georgia that total losses caused by plant diseases and their control costs reached roughly 647.2 million dollars in 2006 and then continued up to 821.85 million dollars in 2013 (Martinez, 2006; 2013). Top ten list of economically and scientifically important plant pathogens includes fungi, bacteria and viruses (Dean et al., 2012; Mansfield et al., 2012; Scholthof et al., 2011; Rybicki, 2015) (Table 1).

\section{[Preferred position for Table 1]}

Plants display different symptoms on leaves, stems and fruits due to plant disease infections (López et al., 2003; Al-Hiary et al., 2011) (Fig.1). These symptoms are particularly useful for visual observation as a conventional first step for plant disease diagnosis but it fails in detecting the presence of pathogen in early infection stages when plant infections are symptomless.

\section{[Preferred position for Fig. 1]}

Early detection of plant pathogens plays an important role in plant health monitoring. It allows to manage disease infections in greenhouse systems and in the field during different stages of plant disease development and also to minimize the risk of the spread of disease infections as well as to prevent introduction of new plant diseases, especially quarantine pathogens at country boarder (Anderson et al., 2004; Strange et al., 2005; Brassier, 2008; Vincelli et al., 2008; Miller et al., 
2009). Many strategies have been widely used for diagnosing plant disease problems including DNA-based methods and immunoassays, for the detection of pathogen protein and nucleic acid extracted from infected plant materials, as direct laboratory based techniques in addition to visual inspection of plant symptoms in the field (López et al., 2003) (Fig. 2A).

On the other hand there are other indirect strategies based on analysis of volatile organic compounds (VOC) that plants release as defense mechanism against pathogen attack (Scala et al., 2013) (Fig.2B). Some recent reviews have described in detail the strategies for monitoring of volatile compounds in plants for disease detection (Sankaran et al., 2010; Nezhad, 2014; Fang and Ramasamy, 2015; Martinelli et al., 2015).

\section{[Preferred position for Fig. 2]}

Several previous studies addressed plant disease diagnosis and pathogen detection using nucleic acid -based methods, mainly consisting of polymerase chain reaction (PCR) followed by DNA hybridization detection, to determine the genetic content of pathogen (Lin et al., 1990; Minsavage et al., 1994; Anwar Haq et al., 2003; Bertolini et al. 2003; Das, 2004; Teixeira et al., 2005; Li et al., 2006; Lacava et al., 2006; Saponari et al., 2008; Urasaki et al., 2008; Fang et al., 2009; Li et al., 2009; Ruiz-Ruiz et al., 2009; Gutiérrez-Aguirre et al., 2009; Yvon et al.,2009). Alternatively, immunoassays, also known as serological assays, including enzyme-linked immunosorbent assay (ELISA), lateral flow devices (LF), tissue print ELISA or direct dot blot immunoassay (DTBIA) have been used to detect the pathogen antigens (Avrameas, 1969; Van Weemen and Schuurs, 1971; Garnsey et al., 1993; Cambra et al., 2000; Nolasco et al. 2002; Holzloehner et al. 2013; Escoffier et al., 2016). Immunoassay technology using monoclonal antibodies offers a high specificity for plant virus detection, being ideal for testing large scale plant samples and for the on-site detection of plant pathogens, as done with tissue print ELISA and LF devices. In contrast, nucleic acid based 
methods are more accurate and specific enough to detect single target pathogen within a mixture containing more than one analyte and highly effective for detection of multiple targets.

In spite of these advantages, molecular detection methods have some limitations in detecting pathogens at low titres in materials such as seeds and insect vectors or at early infection stages. Furthermore, false negative results can be produced from cross contamination with PCR reagents which completely block amplification of target DNA, while false positive results can be generated by cross-amplification of PCR-generated fragments of non-target DNA. . Another limitation is related to the disability to apply PCR for plant pathogen detection in the field (Louws et al. 1999; Schaad and Frederick, 2002; López et al., 2003; Martinelli et al., 2015). To overcome such limitations, innovative and portable biosensors have emerged in the last years, being widely used as diagnostic tools in clinical, environmental and food analysis.

Pathogen biosensing strategies are based on biological recognition using different receptors such as antibodies, DNA probe, phage and others (Eggibs, 2002; Sadanandom and Napier, 2010; Singh et al., 2013) (Fig.3).

\section{[Preferred position for Fig. 3]}

Antibody-based biosensors can allow sensitive and rapid qualitative and quantitative analysis of pathogens offering also label-free possibilities. It is important to note that this general approach is limited by the quality of the antibody employed and its storage condition that could affect antibody stability. Also pathogen size can interfere in some measurements such as the ones based on surface plasmon resonance (SPR). DNA based biosensors show advantages over antibody based ones mostly related to their better sensitivity thanks to the use of nucleic acid amplification techniques, which allows to detect plant pathogen before appearance of disease symptoms. However, they 
have some limitations related to the selection and synthesis of specific DNA probes as well as to the fact that detecting short DNA sequence of long double stranded DNA is a common problem in applying biosensing systems for DNA detection (Skottrup et al., 2008; Fang and Ramasamy, 2015; Hushiarian et al., 2015). Recently, phage-based DNA biosensor for sensing and targeting bacterial plant pathogens has been reported (Fang and Ramasamy, 2015). Bioluminescent-phage based technology was developed for determination the presence of Pseudomonas cannabina pv alisalensis that infects cruciferous vegetables (Schofield et al., 2013). The major advantage of this technology is that detecting nucleic acid of only viable bacterial cells, and as a result, no false positive was obtained. Nevertheless, the reporter phage expression can be inhibited by presence of some chemical compounds in the tested leaves such as thioethers glucosinolate and isothiocyanate.

Along the following sections, the most representative examples of antibody-based and DNA-based plant pathogen detection methods using optical and electrochemical techniques are summarized

(see Table 2), also discussing advantages and limitations. An overview about the commercially available devices will also be shown together with concluding remarks.

\section{ANTIBODY-BASED BIOSENSORS}

\subsection{Electrochemical immunosensors}

Most of the reported electrochemical immunosensors for plant pathogen detection are based on label-free technologies (impedimetric and quartz crystal microbalance-based ones) and enzymatic label-based voltammetric approaches on mercury, gold and carbon electrodes as detailed in the following sections. 


\subsubsection{Voltammetric detection based on the use of enzymes}

In the last three decades, enzyme-linked immunosorbent assay (ELISA) has become the most widely used serological technique in diagnostics since the first publication on using ELISA to quantify rabbit IgG levels (Engvall and Perlmann, 1971). Enzyme immunoassay has been coupled with electrochemical detection methods to diagnose both clinical and plant pathogens with higher sensitivity and selectivity (Rossier et al., 2001; Sarker et al., 2002; Paternolli et al., 2004). This electrochemical enzyme-linked immunoassay (ECEIA) has incorporated enzyme catalysis (enzyme label- substrate complex in presence of $\mathrm{H}_{2} \mathrm{O}_{2}$ ) followed by electrochemical reducing reaction through amperometric and voltammetric techniques (Zhang et al., 1995a, 1995b; Lee et al., 2005). Stable voltammetric peaks are achieved by controlling the $\mathrm{pH}$ of both enzymatic reaction and electrolyte solutions. Highly preferred is the use of Horseradish peroxidase (HRP) and alkaline phosphatase (AP) as enzyme labels since they have a variety of suitable substrates to reach the required sensitivity (Thompson et al., 1991; Jiang et al., 1995). Despite of high sensitivity of these sensing systems, the low availability of enzyme-conjugated antibodies represents an important limitation. Furthermore, enzymatic products can be highly affected by the $\mathrm{pH}$ of the electrolyte solution being another drawback in case of enzymatic reactions occurring in the same medium of the final electrochemical measurement.

Jiao and co-workers (Jiao et al. 2000) applied a voltammetric indirect ELISA based on horseradish peroxidase (HRP) detection system to detect the plant virus called Cucumber mosaic virus (CMV) using two different HRP substrates: $o$-aminophenol (OAP) and $o$-phenylenediamine (OPD). Such indirect ELISA has three main steps: i) immobilization of virus antigen which is either a purified CMV or leaf extract prepared by grinding infected nicotiana leaves with PBS buffer; ii) incubation with specific antibody for CMV detection; iii) immunoreaction with secondary antibody labeled 
with HRP. The current derived from the reduction of the enzymatic product is measured by linear sweep voltammetry using a hanging mercury electrode. The sensitivity found for the ECEIA detection of CMV is almost four to ten times higher than that of the standard spectrophotometric ELISA, reaching detection limits as low as $0.5 \mathrm{ng} / \mathrm{ml}$ using OAD as substrate, also exhibiting high selectivity against four different pathogens: Tobacco mosaic virus (TMV), Potato virus Y (PVY), Southern bean mosaic virus (SBMV), Tomato aspermy virus (ToAV) and Turnip mosaic virus (TuMV).

Recently gold nanoparticles have been used as tags to amplify the analytical signal and significantly enhance the immunological assay's sensitivity. As an example, Zhao and co-workers (Zhao et al. 2014) presented for the first time an ECEIA using gold nanoparticle tags loaded by antibodies labeled with HRP to detect Pantoea stewartii sbusp. stewartii (PSS) plant bacterial pathogen (Fig.4A).

\section{[Preferred position for Fig. 4]}

Linear voltammetric measurements were done in PBS solution containing hydroquinone (HQ) as enzyme substrate and $\mathrm{H}_{2} \mathrm{O}_{2}$ as oxidant agent for monitoring the reduction of benzoquinone (BQ). In comparison to conventional ELISA assay, the ECEIA for PSS detection was 20 times more sensitive, reaching a detection limit of $7.8 \times 10^{3} \mathrm{cfu} / \mathrm{ml}$. Besides sensitivity, this approach enabled sensitive and specific detection of the PSS antigen against other plant bacterial diseases such as panicle blight, leaf streak and Cercospora leaf spot on rice together with black spot of crucifer.

\subsubsection{Label-free electrochemical impedance spectroscopy (EIS)-based detection}

Over two decades ago, impedimetric based immunosensors were introduced by Newman and Martelet using techniques that involve electrochemical impedance spectroscopy (EIS) which 
studies the electrode-solution interface changes and detects that impedance changes produced by biomolecular interactions including DNA hybridization and protein immunocomplex formation (Newman and et al., 1986; Bataillard et al., 1988; Katz and Willner, 2003; K'Owino and Sadik, 2005; Prodromidis, 2007; Daniels and Pourmand, 2007). Although impedance biosensing systems are sensitive and can effectively trace reactions occurring upon, their selectivity in real complex sample is a key problem limiting commercial applications. Most impedimetric biosensors are in label-free format and use self-assembled monolayers (SAMs) as immobilization method to obtain well-ordered monolayers on the surface of the electrode and achieve better antibody-antigen interaction efficiency (Kausaite-Minkstimiene et al., 2010).

Thiol SAMs formation on gold electrodes is the most reported substrate (Porter et al., 1987; Love et al., 2005) that has been used for impedimetric detection of plant pathogens. One of these approaches has been reported by Jarocka and co-workers (Jarocka et al. 2011) for Plum pox virus (PPV) detection on gold electrodes, taking also advantage of AuNPs for stable antibody immobilization while retaining higher biological activity. Anti-PPV antibodies immobilized onto a 1,6-hexanedithiol/AuNPs modified gold electrode were used for the recognition of purified PPV. Leaf extract from infected leaves of nicotiana was also prepared and used as plant virus antigen sources for analysis. The resulting impedimetric PVV immunosensor was more sensitive than conventional detection methods assayed, such as AgriStrip rapid immunochromatographic assay, being able to detect the presence of $0.01 \%$ of infected plant material in the diluted healthy samples with a detection limit of $10 \mathrm{pg} / \mathrm{ml}$.

The same group later reported a similar approach for the detection of Prunus necrotic ringspot virus (PNRSV) using in this case glassy carbon electrodes as platforms and transducers (Jarocka et al. 2013). In this case, they took advantage of protein A, covalently connected to the electrode, 
for anti-PNRSV antibodies immobilization (Fig. 4B). The as-prepared immunosensor was incubated for 30 minutes with leaf extracts from healthy and PNRSV infected cucumber leaves. The stepwise preparation of the immunosensor was verified with electrochemical impedance spectroscopy (EIS) and cyclic voltammetry (CV) observing the expected increase in the electrontransfer resistance $\left(\mathrm{R}_{\mathrm{ct}}\right)$, which was directly measured with EIS. The immunosensor displayed a very good sensitivity and selectivity against Plum pox virus (PPV) and was able to detect PNRSV in plant materials diluted up to ten thousand-fold

\subsubsection{Label-free quartz crystal microbalance-based approaches}

Quartz crystal microbalance (QCM) biosensors are based on recording changes in oscillation frequency on the surface of the crystal that produce electrical field (Kanazawa and Gordon, 1985). QCM-based immunosensors are highly sensitive and allow label-free detection. . Many applications have been reported for detecting foodborne pathogens as well as on environmental and clinical analysis (O'sullivan and Guilbault, 1999; Si et al., 2001; Pohanka et al., 2007; Liu et al., 2007; Bragazzi et al., 2015). Since their use in identifying orchid viruses as a first application for plant disease detection (Eun et al., 2002), a number of piezoelectric label-free immunosensors based on the use of QCM for plant disease determination has been rightly reviewed by Skottrup (Skottrup et al., 2008), and continued in the last years presenting multiplexed detection of three significant plant pathogenic bacteria (Papadakis et al., 2015). We highlight here the recent approach reported by Huang and co-workers (Huang et al., 2014) developing QCM immunosensor based on self-assembled monolayers (SAMs) for identification of Maize chlorotic mottle virus (MCMV). SAMs were formed on the gold surface of QCM crystal layer by layer using mercaptopropanoic and mercaptoundecanoic acids and antibodies specific to MCMV. 
Quantification measurements were obtained by observing the changes in the QCM crystal frequency. This biosensor showed a similar sensitivity as ELISA, recording limit of detection of $250 \mathrm{ng} / \mathrm{ml}$. Moreover the developed immunosensor showed high selectivity against similar viruses, such as Maize Dwarf Mosaic Virus (MDMV) and Wheat streak mosaic virus (WSMV).

In spite of their high sensitivity, QCM-based measurements are highly affected by the environmental conditions, representing an important limitation that should be solved for point-ofcare applications.

\subsection{Optical immunosensors}

Main optical immunosensors for plant pathogen detection are based on lateral flow devices (paperbased sensors), fluorescence approaches and surface plasmon resonance (SPR) systems as explained in the following sections.

\subsubsection{Lateral flow immunoassays (LFIAs)}

Paper-based sensors are well known advantageous devices for diagnostics applications (Parolo and Merkoçi, 2013). Lateral flow (LF) is a paper analytical device, also known as immunochromotographic strip, composed of four different pads: sample pad, made of cellulose, where the sample is dropped; conjugate pad made of glass fiber, impregnated with the bioconjugates solution (label particle and a receptor for the analyte), detection pad, made of nitrocellulose where test line (TL) and control line (CL) are printed and adsorption pad, also made of cellulose (Quesada-González and Merkoçi, 2015). Sandwich and competitive lateral flow immunoassays (LFIAs) are the main LF formats. In a typical sandwich assay, when the sample is 
added on the sample pad the liquid starts flowing to the conjugate pad where the analyte (if present) is linked to the label particles, previously conjugated with a specific bioreceptor. The conjugate flows by capillarity along the detection pad to the absorbent pad, passing through the TL, where it is captured only if the sample has the analyte (positive response), and to the CL, being here always captured, evidencing that the assay works.

In addition to antibodies, aptamers and DNA probes are employed as biological recognition elements which can be labeled with AuNPs, magnetic nanoparticles, fluorescent nanoparticles and enzymes among others so as to generate the color evolution at the test line. The advantages of LFIAs in terms of rapidity, stability and direct on-site analysis make them one of the most popular diagnostic tools in medical diagnostics, food safety, environmental analysis and plant disease detection. Workings with LFIAs have demonstrated very interesting opportunities for signal enhancements via use of nanomaterials (nanoparticles, graphene etc.) in addition to simple changes in platform architecture including vertical flow format. (Parolo et al., 2013a; Parolo et al., 2013b; Rivas et al., 2014; Riva et al., 2015; Morales-Narváez et al., 2015; Nunes-Pauli et al., 2015). The first LFIA for plant pathogen detection was designed to detect Tobacco mosaic virus (TMV) (Tsuda et al., 1992). Since this first design, LFIAs have been proposed for the detection of several plant pathogens (Danks and Barker, 2000). Particularly, LFIAs in sandwich format using AuNPs tags have been utilized to plant viruses such as Citrus tristeza virus (CTV) and Potato virus X (PVX) and also plant pathogenic bacteria like Erwinia amylovora, Banana xanthomonas and Pantoea stewartii as will be commented in the following paragraphs.

Salomone and co-workers (Salomone et al. 2004) developed a LFIA using standard antibodybased sandwich format and AuNPs as label to detect Citrus tristeza virus (CTV) from citrus leaves 
and fruits. Qualitative results showed sensitivity as high as ELISA test with good correlation. The specificity of the assay was also acceptable, obtaining a level of $5 \%$ of false positive results.

A similar approach was later developed for the identification of Potato virus $x$ (Drygin et al. 2012). The reported sensitivity was found to reach $2 \mathrm{ng} / \mathrm{ml}$ while selectivity was tested against major potato seed viruses such as Potato virus $Y$ (PVY), Potato virus $M(\mathrm{PVM})$ and Potato virus $A$ (PVA). Very recently, Feng and co-workers (Feng et al. 2015) performed a rapid detection of Pantoea stewartii sbusp. stewartii (PSS) extracted from corn seed samples using a LFIA (Fig.5A). The LFIA was performed in the presence of three other plant pathogenic bacteria (Burkholderia glumae, Xanthomonas oryzae and Pseudomonas syringae) and none were detected, evidencing an excellent selectivity. The assay displayed a detection limit of $10^{5} \mathrm{cfu} / \mathrm{ml}$ of PSS.

In addition to the use of AuNPs for colorimetric detection, fluorescent tags have also been proposed in LFIAs for plant pathogen detection. This is the case of lanthanide chelate-loaded silica nanoparticles that were used for the determination of Pantoea stewartii sbusp. stewartii (PSS), the bacterial pathogen of Stewart's wilt in sweet corn (Zhang et al. 2014). Samples from healthy and infected corn seeds were analyzed following the standard sandwich assay format. The fluorescence strips allowed to detect a low concentration of PSS $\left(10^{3} \mathrm{cfu} / \mathrm{ml}\right)$ in less than 30 minutes with limit of detection hundredfold lower than ELISA and AuNPs labeled strips.

In spite of their great advantages, LFIAs suffer important limitations related to their low sensitivity and only qualitative/semiquantitative results. Although the sensitivity is highly improved using fluorescent tags as alternative to traditional colorimetric ones, the need of fluorescence reader (no visual detection possibilities) is an important limitation for rapid and in-field qualitative analysis. For this reason, colorimetric LFIAs, mainly based on AuNPs, are still the most commonly used for point-of-care analysis. 


\subsubsection{Fluorescent approaches}

Microsphere sandwich immunoassay technology based on fluorescence-loaded magnetic microsphere and fluorophore- antibodies has been applied for detecting multiple analytes such as biomarkers, food and plant pathogens (Bergervoet et al., 2008; Kim et al., 2010; Mushaben et al., 2013). A recent study has taken a direct application in the use of microsphere immunoassay technology for multiplex plant pathogens simultaneously (Charlermroj et al., 2013). Specific antibodies to plant bacterial pathogen Acidovorax avenae subsp. citrulli (AAC) and three other plant viruses such as Chilli vein-banding mottle virus (CVbMV), Watermelon silver mottle virus (WSMoV) and Melon yellow spot virus (MYSV) were loaded onto a set of fluorescence-coded MagPlex microsphere (Fig.5B). This technology based on measuring the fluorescence intensity of R-phycoerythrin tag enables to determine the antigen of the four plant pathogens. The limits of detection for AAC, CVbMV, WSMoV and MYSV are $6 \times 10^{5} \mathrm{cfu} / \mathrm{ml}, 1.0 \mathrm{ng} / \mathrm{ml}, 20.5 \mathrm{ng} / \mathrm{ml}$ and $35.3 \mathrm{ng} / \mathrm{ml}$, respectively.

\section{[Preferred position for Fig. 5]}

In spite of great advantages, mainly related to sensitivity and ability to detect multiple pathogens in a single assay, the main limitations of these systems are related to the complexity of the assay together with the need of fluorescent readers.

\subsubsection{Surface plasmon resonance (SPR) systems}


Surface Plasmon resonance (SPR) technology is based on monitoring changes of refractive index on the sensor surface after ligand-biomolecule interaction. SPR biosensors have been used in detecting pathogenic microorganism causing microbial contamination, food spoilage and plant infection (Pellequer and Vanregenmortel, 1993; Deisingh and Thompson, 2004; Bergwerff and Van Knapen, 2006; Mazumdar et al., 2008; Dudak and Boyac1, 2009). The most important advantages of this technique rely on the label-free possibilities together with their ability to effectively measure/follow the bioaffinity reactions.

Since more than two decades ago, the first SPR biosensor for Tobacco mosaic virus (TMV) was described (Dubs et al., 1992).

SPR based biosensors have been object of a review (Skottrup et al., 2008) so we detail here some representative examples. For instance, label free biosensors based on SPR were developed to detect plant pathogens including Cowpea mosaic virus, Tobacco mosaic virus and Lettuce mosaic virus as plant viruses and Fusarium culmorum, Phyththora infestans and Puccinia striiformis as fungal plant pathogens (Boltovets et al., 2002; Zezza et al., 2006; Torrance et al., 2006; Skottrup et al., 2007a; Skottrup et al., 2007b). A number of different SPR biosenosrs using DNA probe, antibody and aptamer are reported in the literature for monitoring plant pathogens (Wang et al., 2004; Candresse et al., 2007; Lautner et al., 2010). In very recent years, Lin and co-workers (Lin et al., 2014) developed a label free SPR immunosensor using gold nanorods (AuNRs) for investigation of two viruses of orchid Cymbidium mosaic virus (CymMV) or Odontoglossum ringspot virus (ORSV). Antibodies specific to orchid viruses were modified with AuNRs as sensing layers that offer a wide spectral region help in decreasing the color interference problem caused by sample matrix. This technology was exploited for achieving 48 and $42 \mathrm{pg} / \mathrm{ml}$ as detection limits for CymMV and ORSV, respectively. The stability of the established SPR biosensing system was not 
reported while the specificity was investigated using mixture of target and non-target viral antigen; performances were compared by observing signal changes due to viral antigen- antibody binding on the surface of AuNRs.

In spite of the above mentioned advantages, a serious drawback in the use of this technology are the non-specific adsorptions onto the sensor surface that must be carefully controlled.

\section{DNA-BASED BIOSENSORS}

\subsection{Electrochemical DNA biosensors}

The majority of electrochemical DNA biosensors for plant pathogen determination are based on label-based and label-free voltammetric detection of DNA hybridization. Emerging approaches based on DNA translocation through nanopores, even though not reported yet for plant pathogen detection, show enormous potential in this field so they are also commented in the following sections.

\subsubsection{Label-free DNA hybridization voltammetric detection}

DNA hybridization can be monitored in label-free approaches based on amperometric, impedimetric and voltammetric detection including square-wave voltammetry (SWV), cyclic voltammetry (CV) and differential pulse voltammetry (DPV) (Liu et al., 1999; Azek et al., 2000; Wang et al., 2003; Gao et al., 2007; Lillis et al., 2007). 
An example of voltammetric approach has been recently reported by Malecka and co-workers (Malecka et al. 2014) for the label-free detection of picomolar concentrations of nucleic acid from Plum pox virus (PPV) glassy carbon electrodes. (Fig. 6A). Detection of the pathogen-related DNA, with the complementary target immobilized on the electrode was monitored by Osteryoung square wave voltammetry (OSWV). Voltammetric measurement of electron transfer changes due to the hybridization reaction allowed detecting 22-mer and 42-mer complementary target DNA sequences of PPV at 10-50 pg/ml concentration range. A good discrimination between infected and healthy leaf samples is reported with a detection limit of $12.8 \mathrm{pg} / \mathrm{ml}$ but selectivity of this technique was not characterized by other phytopathogens.

Well-known approaches based on the use of methylene blue (MB) as hybridization indicator have also been recently reported for sugarcane white leaf disease (SWLD) detection (Wongkaew and Poosittisak, 2014). Voltammetric determination of the plant phytoplasma (causal agent of SWLD) was carried out at glassy carbon electrode modified with chitosan. Electrostatic attraction of negatively charged DNA probe to glassy carbon electrode coated with cationic chitosan film for more efficient DNA immobilization, as alternative to covalent immobilization, were used in most of the previously mentioned approaches. Electrochemical detection of hybridization between ssDNA probe and target was performed by cyclic voltammetry (CV) and differential pulse voltammetry (DPV), using MB as a redox indicator, which is covalently attached to guanine bases. The electrochemical reduction of MB decreased after DNA hybridization due to unavailable guanine bases in dsDNA as a complete form, as expected. Following this strategy, a detection limit of $4.7 \mathrm{ng} / \mu \mathrm{l}$ of SWLD DNA was obtained, also distinguishing between target DNA from diseased sugarcane and non-target DNA from both healthy and infected sugarcane plants with other 
pathogens like Sugarcane mosaic virus. This biosensor showed good stability of DNA probe immobilization onto the chitosan with interest to develop an effective specific DNA biosensor.

Gold electrodes modified with nanocomposite membranes made of chitosan (CHIT) and zinc oxide nanoparticles ( $\mathrm{ZnO}$ NPs) were also proposed as platforms for developing sensors for plant pathogen DNA voltammetric detection based on MB redox indicator. This kind of composite can improve the efficiency of the DNA probe immobilization thanks to its good biocompatibility and an enhanced electrochemical conductivity. Such is the case of the system recently proposed for Trichoderma (soil born fungi) determination (Siddiquee et al. 2014). Hybridization between DNA target of Trichoderma and its complementary probe immobilized on the nanocomposite modified electrode was investigated in this case by differential pulse voltammetry (DPV). The fabricated DNA biosensor detected crude DNA taken from real samples (fungal mycelia) with high reproducibility, obtaining a detection limit of $10^{-19} \mathrm{~mol} / \mathrm{L}$. High selectivity for identification of Trichoderma harzianum against other Tricoderma species, probably mainly due to the high specificity of the designed probe DNA used as bioreceptor, has also been reported.

As final remark we can state that, although label-free DNA hybridization using voltammetric systems (and hybridization indicators) have great advantages in terms of low cost of analysis, not necessity of labeling step and possibility of analysis of small volumes, their poor sensitivity in complex real samples should be carefully considered before their application for plant pathogen analysis.

\subsubsection{Nanochannels as emerging tools for electrochemical DNA analysis}


Nanopore/nanochannel-based technologies are currently one of the most promising ones for rapid and efficient DNA analysis (De la Escosura-Muñiz and Merkoçi, 2012). Even though no examples of application for plant pathogen determination using this technology are found yet in the bibliography, we preview that its enormous potential will make it possible in a short time and thus consider of great relevance to include some remarks in this review.

Nanopore/nanochannel biosensing systems are inspired by the microparticle counter device patented by Wallace Coulter more than 60 years ago [Coulter, 1953]. It consists in simply measuring changes in the electrical conductance (electric current or voltage pulse) between two chambers separated by a microchannel when a micro-sized analyte passes through it, giving information about mobility, surface charge, and concentration of the analyte. This sensing principle has been extended in the last decades for nano-sized analytes evaluation using in this case nanometric channels, being the ssDNA analysis extensively reported. The typical approach consists in the monitoring of ssDNA molecules translocation (electrophoretically driven) through a single nanopore (biological or synthetic) which separates two chambers filled with an electrolyte solution (Kasianowicz et al. 1996; Bayley and Cremer, 2001; Siwy and Howorka, 2010). Such translocation produces changes in the constant current measured between the chambers, being the current pulse length characteristic of each of the 4 DNA bases (A, T, C, G). (Fig. 6B). This ability has opened exciting perspectives for DNA sequencing as alternative to conventional real-time PCR. Not only single nanochannels, but also nanochannel arrays have been proposed for the electrical detection of DNA hybridization at the point-of-care (De la Escosura-Muñiz and Merkoçi, 2010).

In addition to DNA, other molecules such as proteins or toxins have been detected using the singlenanochannel technology (De la Escosura-Muñiz and Merkoçi, 2016). We would like also to 
highlight here very recent approaches reported on filamentous virus translocation monitoring through silicon nitride membranes (Mc Mullen et al. 2014) (Fig. 6C). The size and shape of this kind of virus is ideal for the analysis using these systems, since their stiffness avoid hernias formation making them able to pass through the channels in elongated forms, and generating well resolved signatures (easy distinguishable of the ones coming from virus collisions with the membrane), opening the way to reliable future label-free virus detection systems. Such systems could be applied for filamentous virus affecting plants from different genus like closterovirus (CTV) and potyvirus (PVX).

\section{[Preferred position for Fig. 6]}

\subsection{Optical DNA sensors}

Colorimetric detections of gold nanoparticles (AuNPs) in both lateral flow assays and in aggregation tests, together with the use of fluorescent and colorimetric based microarrays and electrochemiluninescence analysis are the most representative examples of optical approaches for plant pathogen DNA detection. The great potential of nanochannel arrays for this purpose is also highlighted in this section.

\subsubsection{Lateral flow assays based on AuNPs}

DNA detection on lateral flow (LF) test strips have been developed for the analysis of different plant diseases, in most cases using gold nanoparticle (AuNP)- labeled DNA probes. As example, a competitive DNA hybridization format was presented by Zhao and co-workers (Zhao et al. 2011) 
for Acidovorax avenae subsp. Citrulli (AAC) bacterial disease of melons.. The developed strip allowed reaching a low detection limit of $0.48 \mathrm{nM}$. The selectivity of the strip was tested against five other plant bacterial pathogens Xanthomonas campestris, Acidovorax avenae, Clavibacter michiganensis, Pesudomonas. syringae and Erwinia carotovora and no cross reactivity was observed.

Another application of DNA hybridization on lateral flow using AuNPs-DNA probe was introduced by Wei and co-workers (Wei et al. 2015) for early detection of Banana bunchy top virus (BBTV). In this case, a direct sandwich assay consisting in AuNPs-DNA as detection probe and biotinylated-DNA as capture probe was developed. (Fig.7). Qualitative and quantitative measurements of test line color were monitored and a linear calibration plot was found between peak area of test line and different concentrations of target DNA, achieving a detection limit of $0.13 \mathrm{nM}$. BBTV-DNA lateral flow biosensor achieved higher sensitivity by ten times in comparison to that of electrophoresis. Selectivity of the strip was evaluated, using plant samples infected with other viruses such as Banana streak virus (BSV) and Cucumber mosaic virus (CMV).

[Preferred position for Fig. 7]

\subsubsection{AuNPs aggregation-based DNA analysis and related approaches}

AuNPs aggregation-based tests have been extensively used for biomolecules detection and also recently proposed for the detection of plant pathogen DNA. These simple approaches are gaining a great attention for diagnostic applications due to visual detection possibility and low cost of analysis. . This is the case of the approach recently reported by Vaseghi and co-workers (Vaseghi 
et al. 2013) who applied this principle for Pseudomonas syringae detection (Fig. 8A). The system was tested using other plant pathogenic bacteria such as Pseudomonas viridiflava, Pectobacterium cartovortum sub cartovorum, Pseudomonas fluoresce, Xanthomonas alfalfae subsp. citrumelonis, Xanthomonas axonopodis pv. citr and Pseudomonas argenus. The results of this assay showed high specificity and sensitivity in detecting as low as $15 \mathrm{ng} / \mathrm{ml}$ of target DNA of P.syringae .

Besides gold aggregation mechanism, bridging flocculation is very well-known approach in colloid chemistry since its introduction in 1950s (Ruehrwein and Ward, 1952). This kind of approach based on reversible adsorption to differentiate between long and short DNA polymers and has been reported recently for rapid detection significant plant pathogens (Wee et al., 2015). This method has been applied for the visual detection of Pseudomonas syringae as plant bacterial pathogen and two other devastating pathogenic plant fungi, Fusarium oxysporum and Botrytis cinerea (Fig. 8B). Key advantage of flocculation is the reliable detection of the presence of pathogens in plants within very early disease stage nevertheless the plants are symptomless. Qualitative analysis enabled detecting of isothermal DNA amplicons as little as $0.5 \mathrm{ng} / \mu \mathrm{l}$

\section{[Preferred position for Fig. 8]}

In spite of the great perspectives of these systems, important parameters like the interparticle gap during DNA duplex formation should be carefully considered in the design of the assay so as to avoid losses in sensitivity.

\subsubsection{Fluorescent and colorimetric approaches in microfluidics and microarrays systems}

Over the last decade, microfluidic chips have been developed as revolution in on-site microbial detection of viruses and bacteria that infect animals and humans (Figeys and Pinto, 2000; Kricka, 
2001; Huang et al., 2010; Wang et al., 2011). First example of the application of a microfluidic system was described for phytopathology detection (Julich et al., 2011). Later a similar approach using microfluidic based on silver nanoparticle that serves as detection agent (label) enables visual detection of fungal pathogens of phytophthora species (Schwenkbier et al., 2015). Besides colorimetric approaches, turbidity-based microfluidic system was developed for determination of viral pathogens infecting orchids such as Cymbidium mosaic virus (CymMV) and Capsicum chlorosis virus (CaCV) (Chang et al., 2013; Lin et al., 2015).

DNA microarray technology for large scale investigation of gene expression variations has been developed (Schena et al., 1995) whereas it is difficult to be suited to automation due to the need of several manual manipulation steps. In 2000s , applications of DNA microarray were reported on identification of pathogens causing plant diseases (Bonants et al., 2002; Bystricka et al., 2002; Nicolaisen, 2002; Perez-Ortin, 2002; Sip, 2002; Schoen et al., 2002,2003; Boonham et al., 2003; Mumford et al., 2006; Zhang and et al., 2013). Recently Wang and Li (Wang and Li, 2007) designed microarray based on DNA sequences labeled with fluorescent tags for visual determination of three fungal plant pathogens (Botrytis cinerea, Didymella bryoniae, and Botrytis squamosa). Glass chip and poldimethylsiloxane (PDMS) have been utilized as substrates for the developed microfluidic microarray. Fluorescence signals to the concentrations of target DNA were measured, detecting as low as $1 \mathrm{fM}$ of DNA. Despite limited application of microarray on plant disease detection, microarray allowed flexible DNA probe formation, rapid DNA hybridization using small sample volume. A complete review addressing microarray application in detecting plant viruses was reported (Boonham et al., 2007; Fig. 9A).

\subsubsection{Electrochemiluminscence-based DNA detection}


The first report of DNA biosensor using Ru(bpy) $3^{+2}$ electrochemiluminescence (ECL) detection protocol appeared in 1991, in which an excited state emitting light was formed as a result of generation of electron transfer reaction between two charged species such as Ru and TPA on electrode surface (Blackburn et al., 1991; Richter, 2004). ECL has various analytical applications in medical diagnosis and environmental analysis (Van Ingen et al., 1998). In spite of the excellent sensitivity of these systems an important limitation appears within solution-based formats that require continuous supply of luminescence reagent. In the recent years, the application of ECL for detection of PCR products is described to quantify plant virus nucleic acid. Tang and coworkers (Tang et al. 2007) introduced for the first time an improved ECL-PCR detection as a diagnostic assay in plant virology, taking advantage of magnetic beads as a separation tool for the hybridization product exploiting the high affinity of biotin-streptavidin. Three plant viruses such as Banana streak virus, Banana bunchy top virus, and Papaya leaf curl virus were amplified by PCR, then hybridized with a tris(bipyridine) ruthenium (TBR)-labeled detector probe and a capture probe labeled with biotin. The hybridization products were captured onto streptavidin coated magnetic beads and the ECL signal of $\mathrm{Ru}(\mathrm{bpy}) 3^{2+}$ (TBR label) was generated by using tripropylamine (TPrA) as the co-reactant. This improved ECL-PCR method held a low detection limit down to $50 \mathrm{fM}$ of PCR products through stable ECL signals. Not evaluated is the selectivity of ECL assay but the results showed many advantages over other detection assays including high sensitivity and stability for plant virus detection.

\subsubsection{Nanochannel arrays as emerging platforms for DNA analysis}

In addition to their properties for electrochemical analysis, nanoporous membranes are also excellent platforms for the development of optical biosensors for DNA analysis. Some nanoporous 
materials (i.e. nanoporous alumina and nanoporous silicon) possess optical properties that are altered by the presence of analytes captured in the inner walls of the nanochannels without the need of any label. Furthermore, fluorescent tags have also been used for DNA monitoring in nanochannels (De la Escosura-Muñiz and Merkoçi, 2012). As in the case of the electrochemical ones, these optical approaches have not yet been applied for plant pathogen detection but we consider of great interest to show here their outstanding potential. The work by Meller's group (McNally et al. 2010) for the optical single-molecule DNA sequencing can be selected as illustrative example. A multicolor readout is used after conversion of the target DNA into a binary code, consisting in the biochemical conversion of the nucleotides to known oligonucleotides. Hybridization with molecular beacons, using two different fluorophores was finally detected by translocating the DNA/beacon complex through the nanochannel. Taking advantage of the nanochannels array, the specific location of each channel in the visual field of the optical detector, allowed the simultaneous readout of the array (Fig. 9B), which open the way to further applications for multidetection of DNA related to plant pathogens.

\section{[Preferred position for Fig. 9]}

\section{COMMERCIAL AVAILABLE DEVICES}

Commercial availability of biological recognition elements (i.e. antibody, DNA probe, aptamer) is a key feature required for successful plant disease diagnosis. To date, most commercialized devices for plant pathogen detection based on immunoassays include lateral flow devices, tissueprint ELISA and plate-ELISA kit (Fig. 10A-D). A variety of commercial kits based on immunoassay have been reported in literature such as pocket kit for orchid virus detection, Agritest lateral flow to detect Erwinia amylovora bacterial causal agent of pome trees moreover Foresite diagnostic commercial kit for xanthomonas wilt of banana plant (Braun-Kiewnick et al., 2011; 
Hodgetts et al. 2015). Polyclonal and monoclonal antisera are available on the market for diagnosis of viral, bacterial and fungal disease in plants for commercial use. Additionally, DNA\& RNA extraction kits have been designed to isolate total nucleic acid from a variety of plant materials, including leaves, bark and fruits. Examples of well tested kits are DNeasy and RNeasy Plant System from Qiagen, ISOLATE plant DNA kit from Bioline and GenElute plant genomic DNA from Sigma company. Emerging mobile applications are helpful tools for farmers in remote areas to detect and identify plant diseases. As example, Gene- $\mathrm{Z}$ is a promising plant disease mobile application based on microfluidic technology; it has applied on quantification of cancer markers. Lately, Gene- $\mathrm{Z}$ is ready to be brought to the market for analyzing plant pathogen in the field and it can be an interesting solution for an effective monitoring / control of plant disease spread. (Fig. 10E).

\section{[Preferred position for Fig. 10]}

\section{CONCLUSIONS}

In this review we show that early detection of old, new and emerging infectious plant disease plays critical role in plant disease management and also could reduce the damage caused by plant diseases worldwide. Conventional diagnostic techniques could be time consuming, are related to special equipment and require still user/professionals with certain experience. To overcome these difficulties, recent advances in micro and nanotechnologies have enabled for developing biosensors for determination of pathogen infections in plants using antibody and DNA as biosensing receptors. This work intensively reviewed the developed antibody-based and nucleic 
acid-based biosensors in laboratories worldwide for plant disease detection. Most DNA biosensors techniques are based on determination of DNA hybridization events including electroluminescence, fluorescent and colorimetric approaches in addition to label-free voltammetric etc. In spite of advantages of DNA biosensors in terms of sensitivity, selectivity due to great recognition properties, their in-field application is still suffering from sample treatment requisites (eg. DNA extraction). On the other hand, antibody-based scenarios have been developed using QCM, SPR, fluorescent, voltammetric and label-free impedance detection techniques. Although one would take advantage of high affinity between antibody and specific antigen (related to plant disease) uncontrolled antibody immobilization could obstruct reaching efficient biosensing signal while developing the right detection tool. Although most of reported biosensors for plant disease detection are still for use at lab level, it is expected that more portable devices will emerge in the future being a strong support for an efficient diagnostic. Given the spread of plant disease there is a strong need to develop new biosensors that can be used directly in the field by farmers themselves. Selection of diagnostic route for plant disease detection relies on the event to be analyzed mainly involving i) phytosanitary analysis \& plant quarantine ii) routine large scale surveys \& disease risk assessment. Sanitary status testing requires the most sensitive method to avoid false positives and discard any pathogen to have pathogen-free mother plants for certification programs. In case of quarantine pathogen monitoring while import/export of plant materials, experts recommend using more than one diagnostic method to reduce the risk of obtaining false (positives or negatives), therefore nucleic acid-based biosensing approaches are being suitable for fast, sensitive testing of small number of samples and for ensuring the quality of disease-free plant materials. However, antibody/antigen interactions methods can be appropriate for testing large number of suspicious plants for surveillance of plant disease spread. Moreover, selecting 
diagnostic method for large-scale plant disease screening to evaluate disease incidence requires proper attention to several aspects such as cost of each single test, availability of on-site evaluation and pre- and post-test probability of disease risk. In addition to the innovative field-based devices, novel approaches are needed to limit the possible introduction and spread of foreign plant diseases across national and international borders. Over the long term, we believe the use of nanotechnology with additional efforts will be helping to significantly develop high sensitive and selective biosensors for real-time monitoring of plant pathogens in the field conditions.

\section{ACKNOWLEDGMENTS}

We acknowledge support from the Spanish MINECO under Project MAT2014-52485-P and through the Severo Ochoa Centers of Excellence Program under Grant SEV-2013-0295. The support from Secretaria d'Universitats i Recerca del Departament d'Economia i Coneixement de la Generalitat de Catalunya (Grant 2014 SGR 260) is also acknowledged.

\section{REFERENCES}

Al-Hiary, H., Bani-Ahmad, S., Reyalat, M., Braik, M., ALRahamneh, Z. (2011). Mach. Learn. 14, 5.

Anderson, P.K., Cunningham, A.A., Patel, N.G., Morales, F.J., Epstein, P.R. ,Daszak, P. 2004. Trends Ecol. Evol. 19:535-44.

Anwar Haq, M., Collin, H.A., Tomsett, A.B., Jones, M.G., 2003. Physiol. Mol. 62 (3), 185-189. Avrameas, S., 1969. Immunochem. 6(1), 43-52.

Azek, F.,Grossiord, C., Joannes, M., Limoges, B., Brossier, P. 2000. Anal. Biochem. 284, 107.

Bataillard, P., Gardies, F., Jaffrezic-Renault, N., Martelet, C., Colin, B., Mandrand, B., 1988. Anal. Chem.. 60(21), 2374-2379. 
Bayley, H., Cremer, P.S. 2001. Nature 413, 226-230.

Bergervoet, J.H., Peters, J., van Beckhoven, J.R., van den Bovenkamp, G.W., Jacobson, J.W., van der Wolf, J.M., 2008. J. Virol. Methods 149(1), 63-68.

Bergwerff, A.A. and Van Knapen, F., 2006. J. AOAC Intern. 89(3), 826-831.

Bertolini, E., Penyalver, R., García, A., Quesada, J.M., Cambra, M., Olmos, A., López,Blackburn, G.F., Shah, H.P., Kenten, J.H., Leland, J., Kamin, R.A., Link, J., Peterman, J., Powell, M.J., Shah, A.,Talley, D.B., 1991.Clin. Chem. 37(9), 1534-1539.

Boltovets, P.M., Boyko, V.R., Kostikov, I.Y., Dyachenko, N.S., Snopok, B.A., Shirshov, Y.M., 2002. J. Virol. Methods 105(1), 141-146.

Boltovets, P.M., Boyko, V.R., Kostikov, I.Y., Dyachenko, N.S., Snopok, B.A., Shirshov, Y.M., 2002. J. Virol. Methods 105(1), 141-146.

Bonants, P., De Weerdt, M., Van Beckhoven, J., Hilhorst, R., Chan, A., Boender, P., Zijlstra, C., Schoen, C., 2002. In: Abstracts Agricultural Biomarkers for Array Technology, Management Committee Meeting, Wadenswil (Vol. 20).

Boonham, N., Tomlinson, J.,Mumford, R., 2007. Annu. Rev. Phytopathol. 45, 307-328.

Boonham, N., Walsh, K., Smith, P., Madagan, K., Graham, I.,Barker, I., 2003. J. Virol. Methods 108(2), 181-187.

Bragazzi, N.L., Amicizia, D., Panatto, D., Tramalloni, D., Valle, I., Gasparini, R., 2015. Adv. Protein Chem. Struct. Biol. 101, 149-211.

Brassier, C.M. 2008. Plant Pathol. 57:792-808.

Braun-Kiewnick, A., Altenbach, D., Oberhänsli, T., Bitterlin, W.,Duffy, B., 2011. J. Microbiol. Methods 87(1), 1-9.

Bystricka, D., Lenz, O., Mraz, I., Dědic, P., Sip, M., 2002. Acta Virol. 47(1), 41-44.

Cambra, M., Gorris, M.T., Román, M.P., Terrada, E., Garnsey, S.M., Camarasa, E., Olmos, A. , Colomer, M., 2000. In 14th Conference of the International Organization of Citrus Virologist. da GRAÇA, JV (34-41).

Candresse, T., Lot, H., German-Retana, S., Krause-Sakate, R., Thomas, J., Souche, S., Delaunay, T., Lanneau, M.,Le Gall, O., 2007. J. Gen. Virol. 88(9), 2605-2610. 
Chang, W.H., Yang, S.Y., Lin, C.L., Wang, C.H., Li, P.C., Chen, T.Y., Jan, F.J., Lee, G.B., 2013. Nanomed.: Nanotech. Biol. Med. 9(8), 1274-1282.

Charlermroj, R., Himananto, O., Seepiban, C., Kumpoosiri, M., Warin, N., Oplatowska, M., Gajanandana, O., Grant, I.R., Karoonuthaisiri, N.,Elliott, C.T., 2013. PloS one 8(4), e62344.

Coulter, W.H., 1953. U.S. Patent 2656508 A.

Daniels, J.S. and Pourmand, N., 2007. Electroanal. 19(12), 1239-1257.

Danks, C. and Barker, I., 2000. EPPO Bulletin 30(3-4), 421-426.

Das, A.K., 2004. Curr. Sci. 87 (9), 1183-1185.

De la Escosura-Muñiz, A., Merkoçi, A. 2010. Chem. Commun. 46, 9007-9009.

De la Escosura-Muñiz, A., Merkoçi, A. 2012. ACS Nano 6 (9), 7556-7583.

De la Escosura-Muñiz, A., Merkoçi, A. 2016. TRAC 79 (2016) 134-150.

Dean, R., Van Kan, J.A., Pretorius, Z.A., Hammond, Kosack, K.E., Di Pietro, A., Spanu, P.D., Rudd, J.J., Dickman, M., Kahmann, R., Ellis, J.,Foster, G.D., 2012. Mol. Plant Pathol. 13(4), 414430.

Deisingh, A.K. and Thompson, M., 2004. Can. J. Microbiol. 50(2), 69-77.

Drygin, Y.F., Blintsov, A.N., Grigorenko, V.G., Andreeva, I.P., Osipov, A.P., Varitzev, Y.A., Uskov, A.I., Kravchenko, D.V.,Atabekov, J.G., 2012. Appl. Microbiol. Biotech. 93(1), 179-189.

Dudak, F.C. and Boyacı, İ.H., 2009. Biotech. J. 4(7), 1003-1011.

Eggibs, B., 2002. Chem. Sensors Biosens., New York.

Engvall, E. and Perlmann, P., 1971. Immunochem. 8(9), 871-874.

Escoffier, L., Ganau, M., Wong, J. 2016. Commercializing nanomedicine: industrial applications, patents, and ethics.

Eun, A.J.C., Huang, L., Chew, F.T., Li, S.F.Y., Wong, S.M., 2002. J. Virol. Methods 99(1), 7179.

Fang, Y. and Ramasamy, R.P., 2015. Biosens. 5(3), 537-561.

Fang, Y., Xu, L.H., Tian, W.X., Huai, Y., Yu, S.H., Lou, M.M., Xie, G.L., 2009. Rice Sci.16 (2), $157-160$.

Feng, M., Kong, D., Wang, W., Liu, L., Song, S.,Xu, C., 2015. Sensors 15(2), 4291-4301. 
Figeys, D. and Pinto, D., 2000. Anal. Chem. 72(9), 330.

Gao, Z., Rafea, S., Lim, L. H.2007. Adv. Mater. 19, 602.

Garnsey, S.M., Permar, T.A., Cambra, M., Henderson, C.T., 1993. In Proc. 12th Conf. IOCV (3950). IOCV Riverside, CA.

Guan, J.G., Miao, Y.Q., Zhang, Q.J., 2004. J. Biosci. Bioeng.97(4), 219-226.

Gutiérrez-Aguirre, I., Mehle, N., Deli` c, D., Gruden, K., Mumford, R., Ravnikar, M., 2009. J. Virol. Methods 162 (1-2), 46-55.

Hodgetts, J., Karamura, G., Johnson, G., Hall, J., Perkins, K., Beed, F., Nakato, V., Grant, M., Studholme, D.J., Boonham, N.,Smith, J., 2015. Plant Pathol. 64(3), 559-567.

Holzloehner, P., Schliebs, E., Maier, N., Funer, J., Micheel, B., Heilmann, K., 2013. J. Immunol. 190(Meeting Abstracts 1), 135-14.

Huang, C.H., Lai, G.H., Lee, M.S., Lin, W.H., Lien, Y.Y., Hsueh, S.C., Kao, J.Y., Chang, W.T., Lu, T.C., Lin, W.N., Chen, H.J., 2010. J. App. Microbiol. 108(3), 917-924.

Huang, X., Xu, J., Ji, H.F., Li, G., Chen, H., 2014. Anal. Methods 6(13), 4530-4536.

Hushiarian, R., Yusof, N.A., Abdullah, A.H., Ahmad, S.A.A., Dutse, S.W., 2015. Anal. Chem. Res. 6, 17-25.

Jarocka, U., Radecka, H., Malinowski, T., Michalczuk, L.,Radecki, J., 2013. Electroanal. 25(2), 433-438.

Jarocka, U., Wąsowicz, M., Radecka, H., Malinowski, T., Michalczuk, L.,Radecki, J., 2011. Electroanal. 23(9), 2197-2204.

Jiang, T., Halsall, H.B., Heineman, W.R., Giersch, T.,Hock, B., 1995. J. Agric.Food Chem. 43(4, 1098-1104.

Jiao, K., Sun, W., Zhang, S.S., 2000. Fresenius' J. Anal. Chem. 367(7), 667-671.

Julich, S., Riedel, M., Kielpinski, M., Urban, M., Kretschmer, R., Wagner, S., Fritzsche, W., Henkel, T., Möller, R. and Werres, S., 2011. Biosens. Bioelectron. 26(10), 4070-4075.

Kanazawa, K.K. and Gordon, J.G., 1985. Anal.Chem. 57(8),1770-1771.

Kasianowicz, J., Brandin, E., Branton, D., Deamer, D. 1996. Proc. Natl. Acad. Sci. USA, 93, 13770-13773.

Katz, E. and Willner, I., 2003. Electroanal. 15(11), 913-947. 
Kausaite-Minkstimiene, A., Ramanaviciene, A., Kirlyte, J., Ramanavicius, A., 2010. Anal. Chem. 82(15), 6401-6408.

Kim, J.S., Taitt, C.R., Ligler, F.S., Anderson, G.P., 2010. Sens. Instrum. Food Qual. Saf. 4(2), 73 81.

K'Owino, I.O. and Sadik, O.A., 2005. Electroanal. 17(23), 2101-2113.

Kricka, L.J., 2001. Clin. Chim. Acta 307(1), 219-223.

Lacava, P.T., Li, W.B., Araújo, W.L., Azevedo, J.L., Hartung, J.S., 2006. J. Microbiol.Methods $65,535-541$.

Lautner, G., Balogh, Z., Bardóczy, V., Mészáros, T., Gyurcsányi, R.E., 2010. Analyst 135(5), 918-926.

Lee, H.Y., Jung, H.S., Fujikawa, K., Park, J.W., Kim, J.M., Yukimasa, T., Sugihara, H.,Kawai, T., 2005. Biosens. Bioelectron. 21(5), 833-838.

Li, W., Abad, J.A., French-Monar, R.D., Rascoe, J., Wen, A., Gudmestad, N.C., Secor, G.A., Lee, I.M., Duan, Y., Levy, L., 2009. J. Microbiol.Methods 78 (1), 59-65.

Li, W., Hartung, J.S., Levy, L., 2006. J. Microbiol.Methods 66 (1), 104-115.

Lillis, B., Manning, M., Hurley, E., Berney, H., Duane, R., Mathewson, A., Sheehan, M. M.2007. Biosens. Bioelectron. 22,1289.

Lin, C.L., Chang, W.H., Wang, C.H., Lee, C.H., Chen, T.Y., Jan, F.J., Lee, G.B., 2015. Biosens. Bioelectron.63, 572-579.

Lin, H.Y., Huang, C.H., Lu, S.H., Kuo, I.T., Chau, L.K., 2014. Biosens. Bioelectron. 51, 371-378. Lin, N.S., Hsu, Y.H., Hsu, H.T. 1990. Phytopathol. 80(9), 824-828.

Liu, F., Li, Y., Su, X.L., Slavik, M.F., Ying, Y., Wang, J., 2007. Sens. Instrum. Food Qual. Saf. 1(4), 161-168.

Liu, X. J., Tan, W. H. 1999. Anal. Chem. 71, 5054.

López, M.M., Bertolini, E., Olmos, A., Caruso, P., Gorris, M.T., Llop, P., Penyalver, R., Cambra, M. 2003. Int. Microbiol.6, 233-243.

Louws, F.J., Rademaker, J.L.W., De Bruijn, F.J., 1999. Annu. Rev. Phytopathol. 37(1), 81-125.

Love, J.C., Estroff, L.A., Kriebel, J.K., Nuzzo, R.G., Whitesides, G.M., 2005. Chem. Rev. 105,1103-1169. 
Malecka, K., Michalczuk, L., Radecka, H.,Radecki, J., 2014. Sensors 14(10), 18611-18624.

Mansfield, J., Genin, S., Magori, S., Citovsky, V., Sriariyanum, M., Ronald, P., Dow, M.A.X., Verdier, V., Beer, S.V., Machado, M.A., Toth, I.A.N., 2012. Mol. Plant Pathol.6), 614-629.

Martinelli, F., Scalenghe, R., Davino, S., Panno, S., Scuderi, G., Ruisi, P., Villa, P., Stroppiana, D., Boschetti, M., Goulart, L.R., Davis, C.E., 2015. Agron. Sustain.e Dev. 35(1), 1-25.

Martinez, A. (2006). 2006 Georgia Plant Disease Loss Estimates.

Martinez, A. (2013). 2013 Georgia Plant Disease Loss Estimates.

Mazumdar, S.D., Barlen, B., Kramer, T., Keusgen, M., 2008. J. Microbiol. Methods 75(3), 545550.

McMullen, A., de Haan, H.W., Tang, J.X., Stein, D. 2014. Nat. Commun. 5, 4171.

McNally, B., Singer, A., Yu, Z., Sun, Y., Weng, Z., Meller, A. 2010. Nano Lett. 10, 2237-2244.

Miller, S.A., Beed, F.D., Harmon, C.L. 2009. Annu. Rev.Phytopathol. 47:15-38.

Minsavage, G.V., Thompson, C.M., Hopkins, D.L., Leite, R.M.V.B.C., Stall, R.E., 1994. Phytopathol. 84, 456-461.

Morales-Narváez, E., Naghdi, T., Zor, E. and Merkoçi, A., 2015. Anal.Chem. 87(16), 8573-8577.

Mumford, R.A., Jarvis, B., Harju, V., Boonham, N., Skelton, A., 2006. Plant Pathol. 55(6),819819.

Mushaben, E.M., Brandt, E.B., Hershey, G.K.K., Le Cras, T.D., 2013. PloS one 8(1), e54426.

Newman, A. L., Hunter, K. W., Stanbro, W. D., 1986. Proc. 2ndInt. Meet. Chem. Sens. 596-598.

Nezhad, A.S., 2014. Lab on a Chip 14(16), 2887-2904.

Nicolaisen, M., 2002. In: Abstracts Agricultural Biomarkers for Array Technology, Management Committee Meeting, Wadenswil (vol. 22).

Nolasco, G., Sequeira, Z., Soares, C., Mansinho, A., Bailey, A.M., Niblett, C.L., 2002. Eur. J. Plant Pathol.108(4), 293-298.

Nunes Pauli,G.E.,de la Escosura-Muñiz, A., Parolo, C., Bechtold, I.H. and Merkoçi, A., 2015. Lab on a Chip 15(2), 399-405.

O’sullivan, C.K. and Guilbault, G.G., 1999. Biosens. Bioelectron. 14(8), 663-670.

Oerke, E.-C. 2006. J. Agric. Sci. 144, 31-43. 
Papadakis, G., Skandalis, N., Dimopoulou, A., Glynos, P., Gizeli, E., 2015. PloS one 10(7), e0132773.

Parolo, C. and Merkoçi, A., 2013. Chem. Soc. Reviews 42(2), 450-457.

Parolo, C., de la Escosura-Muñiz, A. and Merkoçi, A., 2013a. Biosens. Bioelectron. 40(1), 412416.

Parolo, C., Medina-Sánchez, M., de la Escosura-Muñiz, A. and Merkoçi, A., 2013b. Lab on a Chip 13(3), 386-390.

Paternolli, C., Antonini, M., Ghisellini, P., Nicolini, C., 2004. Langmuir 20(26), 11706-11712.

Perez-Ortin, J.E., 2002. In: Abstracts Agricultural Biomarkers for Array Technology, Management Committee Meeting, Wadenswil (vol. 13).

Pimentel, D., Zuniga, R., Morrison, D. 2005. Ecol. Econ. 52, 273-288.

Pohanka, M., Skládal, P., Pavliš, O., 2007. J. Immunoass. Immunochem. 29(1), 70-79.

Porter, M.D., Bright, T.B., Allara, D.L., Chidsey, C.E., 1987. J Am. Chem. Soc. 109(12), 35593568 .

Prodromidis, M.I., 2007. Pak. J. Anal. Environ. Chem. 2,69-71.

Quesada-González, D. and Merkoçi, A., 2015. Biosens. Bioelectron. 73, 47-63.

Richter, M.M., 2004. Chem. Reviews 104(6), 3003-3036.

Rivas, L., de la Escosura-Muñiz, A., Serrano, L., Altet, L., Francino, O., Sánchez, A. and Merkoçi, A., 2015. Nano Res. 8(11), 3704-3714.

Rivas, L., Medina-Sánchez, M., de la Escosura-Muñiz, A. and Merkoçi, A., 2014. Lab on a Chip 14(22), 4406-4414.

Roberts, M.J., Schimmelpfennig, D.E., Ashley, E., Livingston, M.J., Ash, M.S., Vasavada, U., The Value of Plant Disease Early-Warning Systems: A Case Study of USDA's Soybean Rust Coordinated Framework; United States Department of Agriculture, Economic Research Service: Washington, DC, USA, 2006.

Rossier, J.S. and Girault, H.H., 2001. Lab on a Chip 1(2), 153-157.

Ruehrwein, R.A. and Ward, D.W., 1952. Soil Sci. 73(6), 485-492.

Ruiz-Ruiz, S., Ambrós, S., Carmen Vives, M., Navarro, L., Moreno, P., Guerri, J., 2009. J. Virol. Methods 160 (1-2), 57-62. 
Rybicki, E. P. (2015). Arch. Virol. 160(1) , 17-20.

Sadanandom, A., Napier, R.M. 2010. Curr. Opin. Plant Biol. 13, 736-743.

Salomone, A., Mongelli, M., Roggero, P.,Boscia, D., 2004. J. Plant Pathol. 43-48.

Sankaran, S., Mishra, A., Ehsani, R. and Davis, C., 2010. Comput. Electron. Agric. 72(1), 1-13.

Saponari, M.,Manjunath, K., Yokomi, R.K., 2008. J Virol. Methods 147 (1), $43-53$.

Sarkar, P., Pal, P.S., Ghosh, D., Setford, S.J.,Tothill, I.E., 2002. Int. J. Pharm. 238(1), 1-9.

Savary, S., Ficke, A., Aubertot, J., Hollier, C. 2012. Food Secur. 4, 519-537.

Scala, A., Allmann, S., Mirabella, R., Haring, M.A., Schuurink, R.C., 2013. Int. J. Mol. Sci. 14(9), 17781-17811.

Schaad, N.W., Frederick, R.D., 2002. Can. J. Plant Pathol. 24(3), 250-258.

Schoen, C., De Weerdt, M., Hillhorst, R., Boender, P., Szemes, M., Bonants, P., 2003. In: Abstracts of the 19th International Symposium on Virus and Virus-like Diseases of Temperate Fruit Crops, Valencia (vol. 108).

Schoen, C., De Weerdt, M., Hillhorst, R., Chan A., Boender, P., Zijlstra, C., Bonants, P., 2002. In: Abstracts Agricultural Biomarkers for Array Technology, Management Committee Meeting, Wadenswil (vol. 11).

Schofield, D.A., Bull, C.T., Rubio, I., Wechter, W.P., Westwater, C.,Molineux, I.J., 2013. Bioengineered 4(1), 50-54.Siddiquee, S., Rovina, K., Yusof, N.A., Rodrigues, K.F.,Suryani, S., 2014. Sens. Biosensing Res. 2, 16-22.

Scholthof, K.B.G., Adkins, S., Czosnek, H., Palukaitis, P., Jacquot, E., Hohn, T., Hohn, B., Saunders, K., Candresse, T., Ahlquist, P., Hemenway, C. 2011. Mol. Plant Pathol. 12(9), 938-954. Schwenkbier, L., Pollok, S., König, S., Urban, M., Werres, S., Cialla-May, D., Weber, K., Popp, J., 2015. Anal.Methods 7(1), 211-217.

Si, S.H., Li, X., Fung, Y.S., Zhu, D.R., 2001. Microchem. J. 68(1), 21-27.

Singh, A., Poshtiban, S., Evoy,S., 2013. Sens. 13(2), 1763-1786.

Sip, M., 2002. In: Abstracts Agricultural Biomarkers for Array Technology, Management Committee Meeting, Wadenswil (vol.24).

Siwy, Z.S., Howorka, S. 2010. Chem. Soc. Rev. 39, 1115-1132. 
Skottrup, P., Hearty, S., Frøkiær, H., Leonard, P., Hejgaard, J., O’Kennedy, R., Nicolaisen, M., Justesen, A.F., 2007a. Biosens. Bioelectron. 22(11), 2724-2729.

Skottrup, P., Nicolaisen, M., Justesen, A.F., 2007b. J. Microbiol. Methods 68(3), 507-515.

Skottrup, P.D., Nicolaisen, M., Justesen, A.F., 2008. Biosens. Bioelectron. 24(3), 339-348.

Strange, R.N, Scott, P.R. 2005. Annu. Rev. Phytopathol.43:83-116.

Sun, W., Jiao, K., Zhang, S., 2001. Talanta 55(6), 1211-1218.

Tang, Y.B., Xing, D., Zhu, D.B.,Liu, J.F., 2007. Anal. Chim. Acta 582(2), 275-280.

Teixeira, D.C., Danet, J.L., Eveillard, S., Martins, E.C., Junior, W.C.J., Yamamoto, P.T., Lopes, S.A., Bassanezi, R.B., Ayres, A.J., Saillard, C., Bové, J.M., 2005. Mol. Cell. Probes 19, 173-179. Thompson, R.Q., Barone, G.C., Halsall, H.B.,Heineman, W.R., 1991. Anal. Biochem. 192(1), 9095.

Torrance, L., Ziegler, A., Pittman, H., Paterson, M., Toth, R., Eggleston, I., 2006. J. Virol. Methods 134(1), 164-170.

Tsuda, S., Kameya-Iwaki, M., Hanada, K., Kouda, Y., Hikata, M., Tomaru, K., 1992. Plant Dis. 76(5), 466-469.

Urasaki, N., Kawano, S., Mukai, H., Uemori, T., Takeda, O., Sano, T., 2008. J. Gen. Plant Pathol. $74,151-155$.

Van Ingen, H.E., Chan, D.W., Hubl, W., Miyachi, H., Molina, R., Pitzel, L., Ruibal, A., Rymer, J.C., Domke, I., 1998. Clin. Chem. 44(12), 2530-2536.

Van Regenmortel, M.H., Pellequer, J.L., 1993. Pept. Res. 7(4), 224-228.

Van Weemen, B.K., Schuurs, A.H.W.M. 1971. FEBS letters 15(3), 232-236.

Vaseghi, A., Safaie, N., Bakhshinejad, B., Mohsenifar, A., Sadeghizadeh, M., 2013. Sens. Actuators B- Chem. 181, 644-651.

Vincelli, P., Tisserat, N. 2008. Plant Dis. 82:660-69.

Wang, C.H., Lien, K.Y., Wu, J.J., Lee, G.B., 2011. Lab on a Chip 11(8), 1521-1531.

Wang, J., Li, J. H., Baca, A. J., Hu, J. B., Zhou, F. M., Yan, W.,Pang, D. W.2003. Anal. Chem. 75,3941 .

Wang, R., Minunni, M., Tombelli, S., Mascini, M., 2004. Biosens. Bioelectron. 20(3), 598-605. 
Wee, E.J.H., Lau, H.Y., Botella, J.R.,Trau, M., 2015. Chem. Commun. 51(27), 5828-5831.

Wongkaew, P. and Poosittisak, S., 2014. Am. J. Plant Sci. 2014.

Yvon, M., Thébaud, G., Alary, R., Labonne, G., 2009. Mol. Cell Probes 23 (5), 227-234.

Zezza, F., Pascale, M., Mulè, G., Visconti, A., 2006. J. Microbial. Methods 66(3), 529-537.

Zhang, F., Zou, M., Chen, Y., Li, J., Wang, Y., Qi, X.,Xue, Q., 2014. Biosens. Bioelectron. 51, 29-35.

Zhang, Y., Jiao, K., Liu, C., Yang, Z.X., 1995a. Electroanal. 7(3),283-286.

Zhang, Y., Jiao, K., Liu, C., Yang, Z.X., 1995b. Electroanal. 7(3), 283-286.

Zhang, Y., Yin, J., Jiang, D., Xin, Y., Ding, F., Deng, Z., Wang, G., Ma, X., Li, F., Li, G., Li, M., 2013. PloS one 8(5), e64474.

Zhao, W., Lu, J., Ma, W., Xu, C., Kuang, H.,Zhu, S., 2011. Biosens. Bioelectron. 26(10), 42414244.

Zhao, Y., Liu, L., Kong, D., Kuang, H., Wang, L., Xu, C., 2014. ACS App. Mater. Interfaces 6(23), 21178-21183.

http://extension.uga.edu/publications/files/pdf/SB\%2041-09_3.PDF. Viewed on Sunday, 22, May, 2016.

http://extension.uga.edu/publications/files/pdf/AP\%20102-6_1.PDF. Viewed on Sunday, 22, May, 2016.

http://www.crec.ifas.ufl.edu/extension/greening/symptoms.shtml. Viewed on Sunday, 22, May, 2016. 


\section{TABLES}

Table 1. Top ten important plant pathogenic bacteria, fungi and viruses published by Molecular Plant pathology (Dean et al., 2012; Mansfield et al., 2012; Scholthof et al., 2011; Rybicki, 2015)

\begin{tabular}{clll}
\hline $\begin{array}{c}\text { plant } \\
\text { pathogen }\end{array}$ & \multicolumn{1}{c}{ Fungi } & \multicolumn{1}{c}{ Bacteria } & \multicolumn{1}{c}{ Virus } \\
\hline 1 & Magnaporthe oryzae & Pseudomonas syringae & Tobacco mosaic virus \\
2 & Botrytis cinerea & Ralstonia solanacearum & Tomato spotted wilt \\
3 & Puccinia spp. & Agrobacterium tumefaciens & Tomato yellow leaf curl \\
4 & Fusarium graminearum & Xanthomonas oryzae & Cucumber mosaic \\
5 & Fusarium oxysporum & Xanthomonas campestris & Potato virus Y \\
6 & Blumeria graminis & Xanthomonas axonopodis & Cauliflower mosaic \\
7 & Mycosphaerella & Erwinia amylovora & African cassava mosaic \\
8 & Colletotrichum spp & Xylella fastidiosa & Plum pox \\
9 & Ustilago maydis & Dickeya (dadantii and solani) & Brome mosaic \\
10 & Melampsora lini & Pectobacterium carotovorum & Potato virus X \\
\hline
\end{tabular}


Table 2. Summary of various biosensing techniques used for plant pathogen detection

Biosensors Detection $\quad$ Assay format $\quad$ Sensing plant pathogen

Electrochemical/Enzyme label

Electrochemical/AuNPs tag

Electrochemical/label-free

\section{Antibody-}

based

Optical/AuNPs tag

Optical/ fluorescent tag

Optical/ label free

Electrochemical/label-free

Optical/AuNPs tags

DNA-based

Optical/magnetic tag

Optical/fluorescent tag

Optical/ luminescent tag
- Voltammetric Enzyme-based detection

- Electrochemical impedance spectroscopy (EIS)-based detection

- Quartz crystal microbalance-based approaches

- Lateral Flow immunoassays

- Fluorescent approaches

- Surface plasmon resonance (SPR) systems

- DNA hybridization voltammetric detection

- Lateral Flow immunoassays

- AuNPs aggregation-based DNA analysis

- bridging flocculation

- Fluorescent approach in DNA microarrays

- Electrochemiluminscence-based DNA detection
- Cucumber mosaic virus

- Pantoea stewartii sbusp. stewartii

- Plum pox virus

- Prunus necrotic ringspot virus

- Maize chlorotic mottle virus

- Potato virus $x$

- Pantoea stewartii sbusp. Stewarti

- Pantoea stewartii sbusp. Stewartii

- Acidovorax avenae subsp. citrulli

- Chilli vein-banding mottle virus

- Watermelon silver mottle virus

- Melon yellow spot virus

- Cymbidium mosaic virus

- Odontoglossum ringspot virus

- Plum pox virus

- sugarcane white leaf disease

- Trichoderma harzianum

- Acidovorax avenae subsp. Citrulli

- Banana bunchy top virus

- Pseudomonas syringae

- Pseudomonas syringae

- Botrytis cinerea

- Banana streak virus

- Banana bunchy top virus
- $0.5 \mathrm{ng} / \mathrm{ml}$

- $7.8 \times 10^{3} \mathrm{cfu} / \mathrm{ml}$

- $10 \mathrm{pg} / \mathrm{ml}$

- Not reported

- $250 \mathrm{ng} / \mathrm{ml}$.

- $2 \mathrm{ng} / \mathrm{ml}$

- $10^{5} \mathrm{cfu} / \mathrm{ml}$

- $10^{3} \mathrm{cfu} / \mathrm{ml}$

- $6 \times 10^{5} \mathrm{cfu} / \mathrm{ml}$

- $1.0 \mathrm{ng} / \mathrm{ml}$

- $20.5 \mathrm{ng} / \mathrm{ml}$

- $35.3 \mathrm{ng} / \mathrm{ml}$

- $48 \mathrm{pg} / \mathrm{ml}$

- $42 \mathrm{pg} / \mathrm{ml}$

- $12.8 \mathrm{pg} / \mathrm{ml}$

- $4.7 \mathrm{ng} / \mu \mathrm{l}$

- $10^{-19} \mathrm{~mol} / \mathrm{L}$

- $0.48 \mathrm{nM}$

- $0.13 \mathrm{nM}$

- $15 \mathrm{ng} / \mathrm{ml}$

- $0.5 \mathrm{ng} / \mu \mathrm{l}$

- $1 \mathrm{fM}$

- $50 \mathrm{fM}$

- $50 \mathrm{fM}$ 
FIGURES

TOC FIGURE

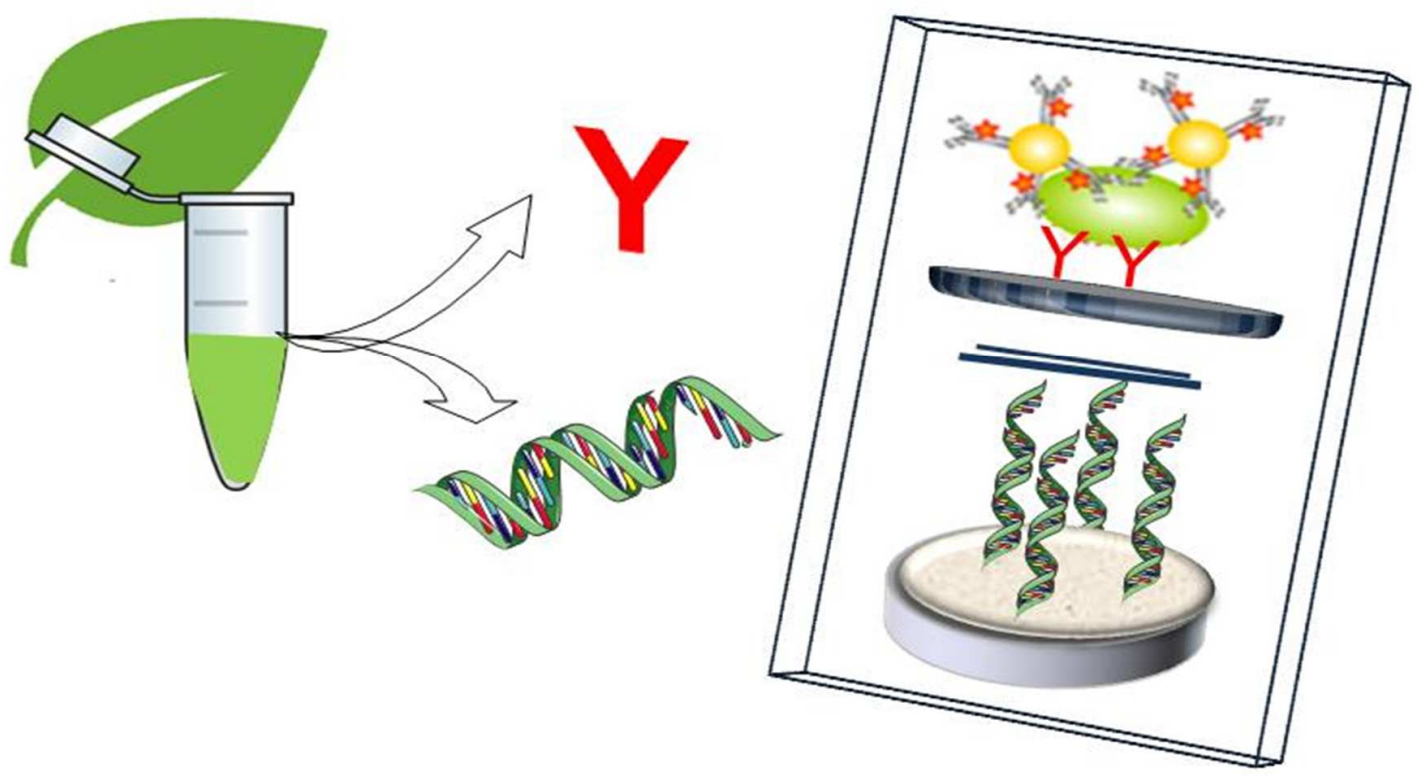



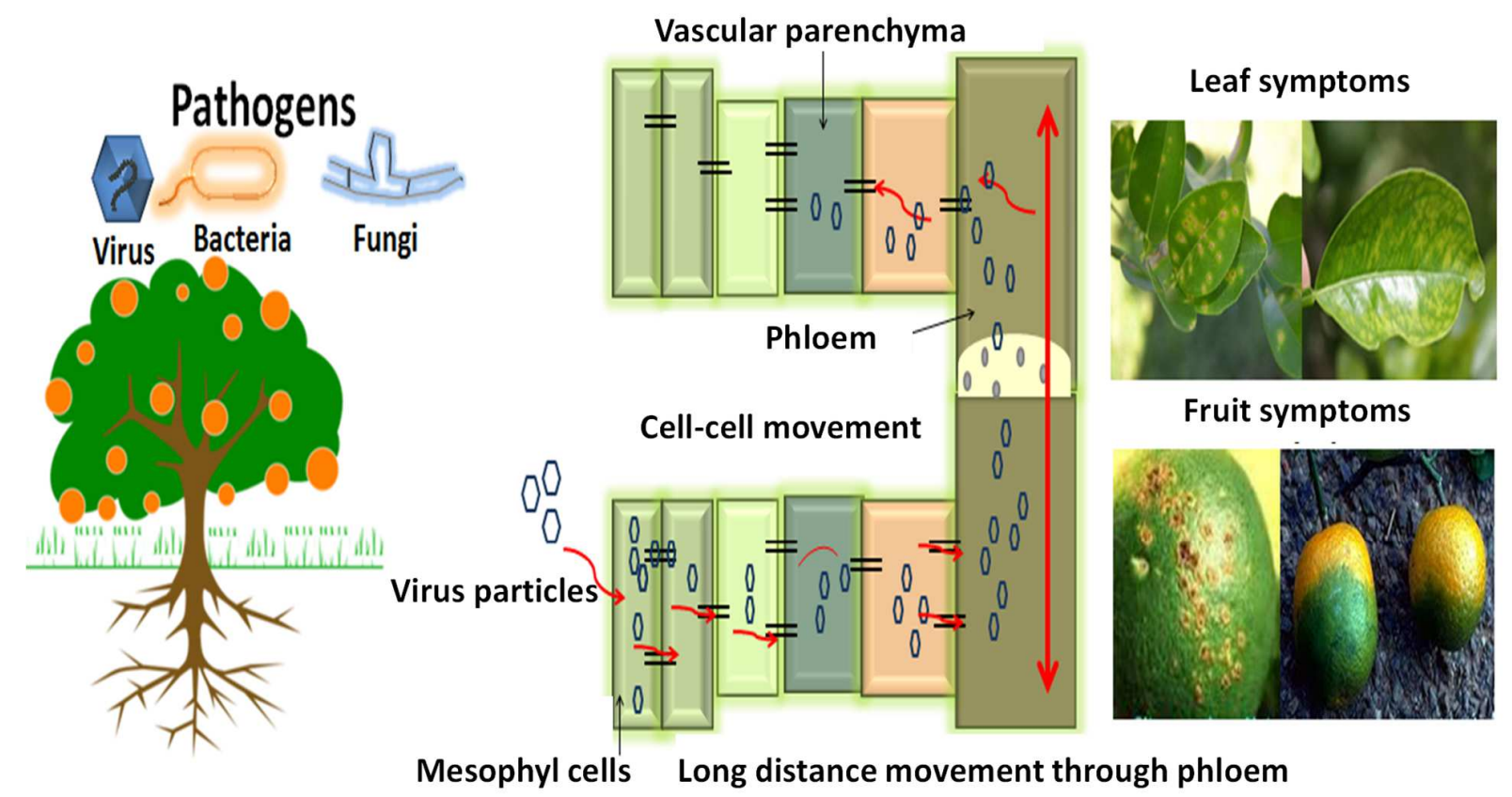

Fig.1 Illustration of bacterial disease symptoms on citrus leaves and fruits. Adapted with permission from http://www.crec.ifas.ufl.edu/extension/greening/symptoms.shtml 

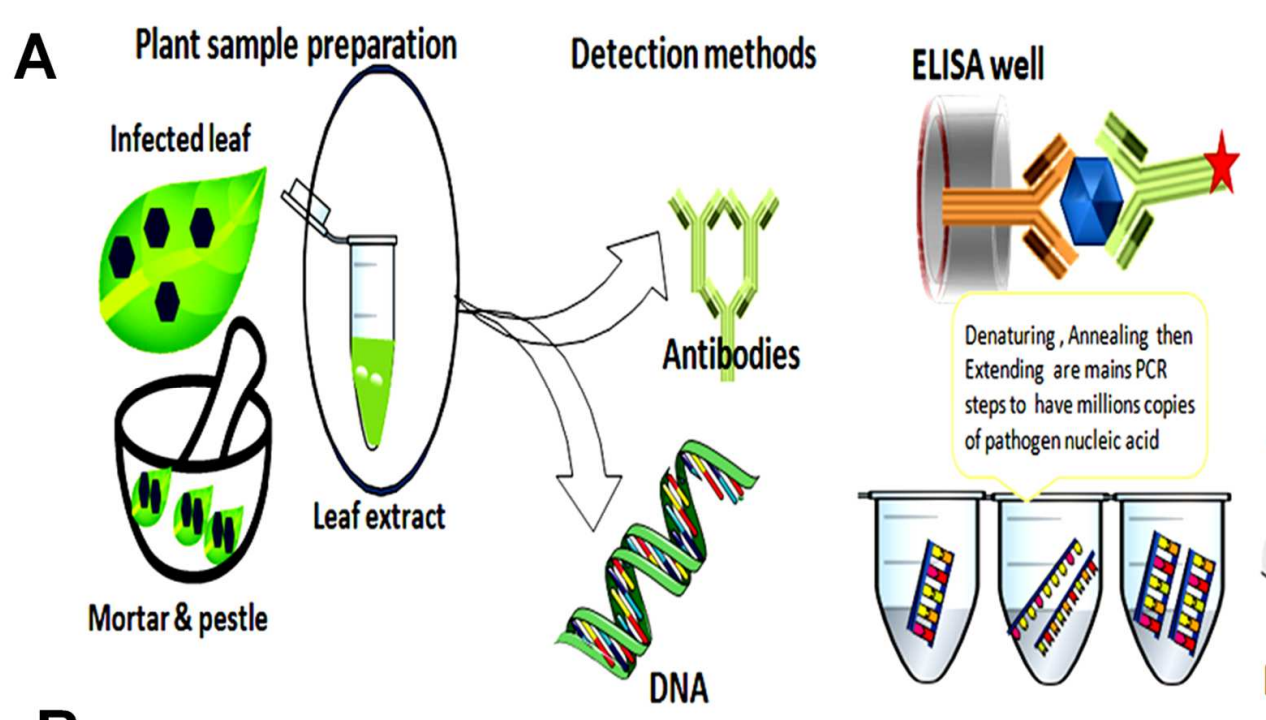

Development of color indicates the presence of pathogen

B

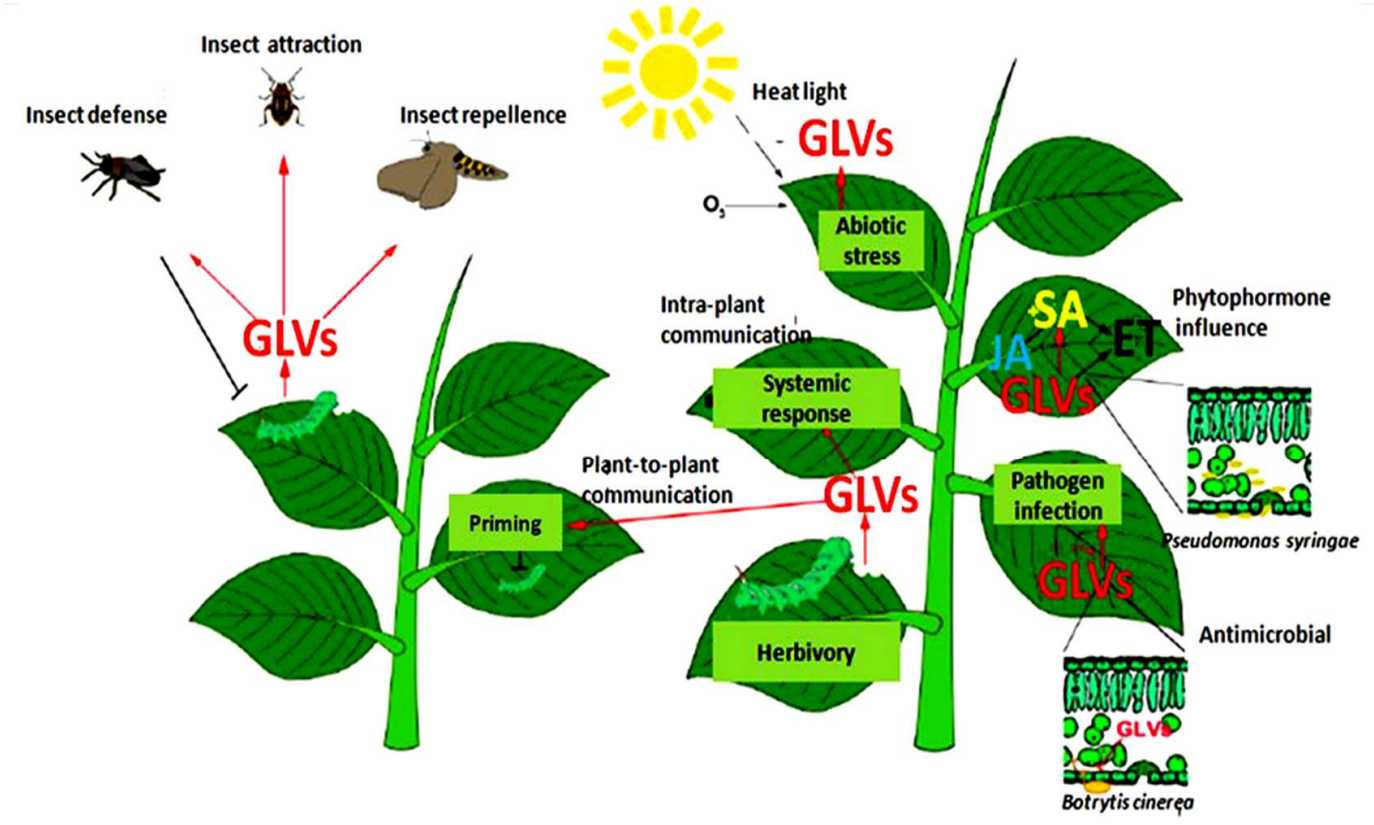

Fig. 2 (A) Schematic representation of the procedure for leaf extraction for pathogenic protein and DNA detection based on ELISA and PCR respectively. (B) Illustration of the green leaf volatiles (GLVs: jasmonic acid (JA), salicylic acid (SA) and ethylene (ET)) released during herbivory, pathogen infection and abiotic stress. Adapted with permission from (Scala et al. 2013). 

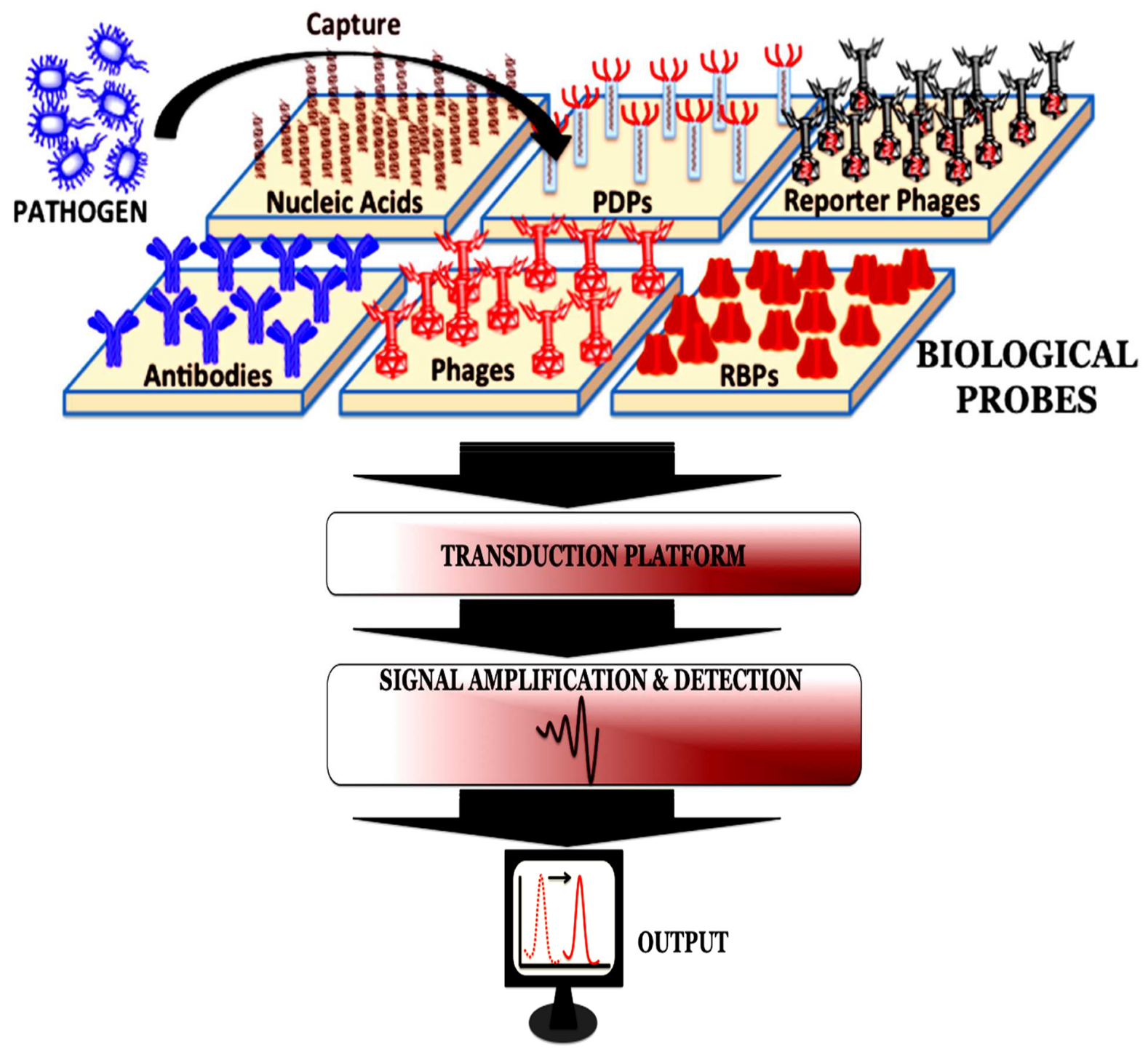

Fig. 3 Schematic of pathogen identification strategies using different biological recognition probes including antibodies, DNA probe, phage, PDPs (phage display peptides) and RBPs (phage receptor binding proteins). Adapted with permission from (Singh et al. 2013). 
A

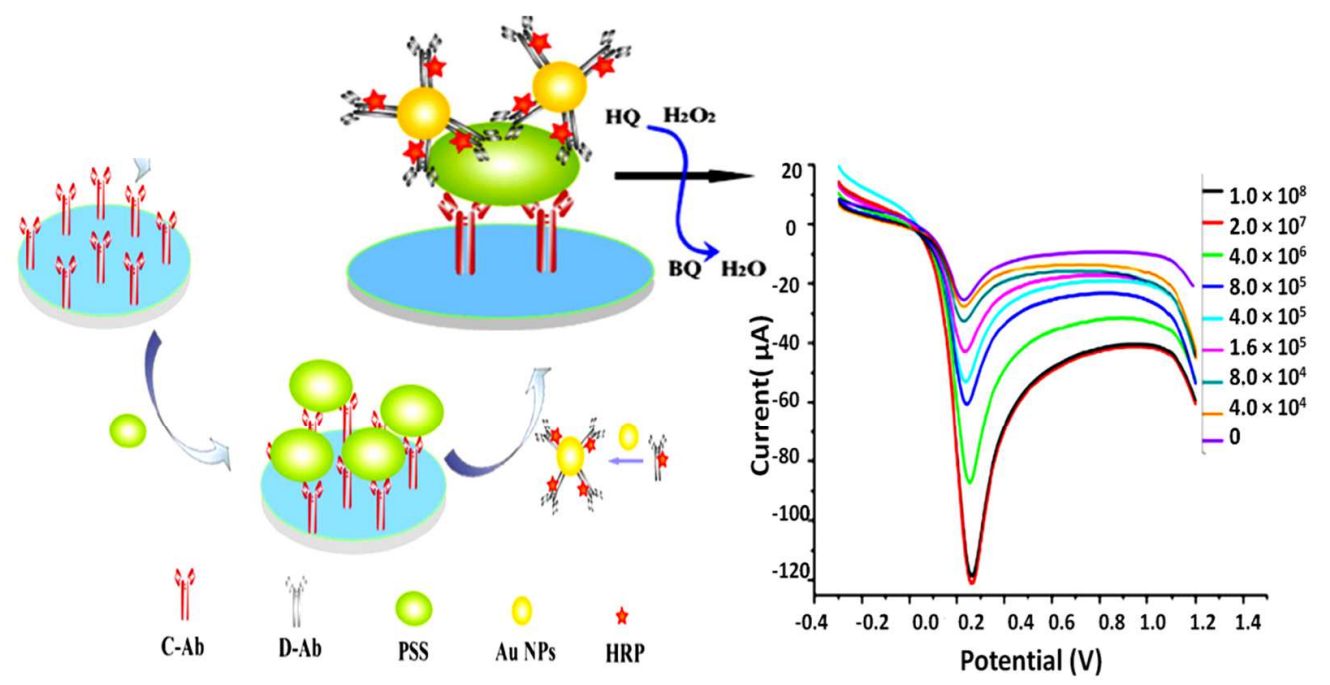

B
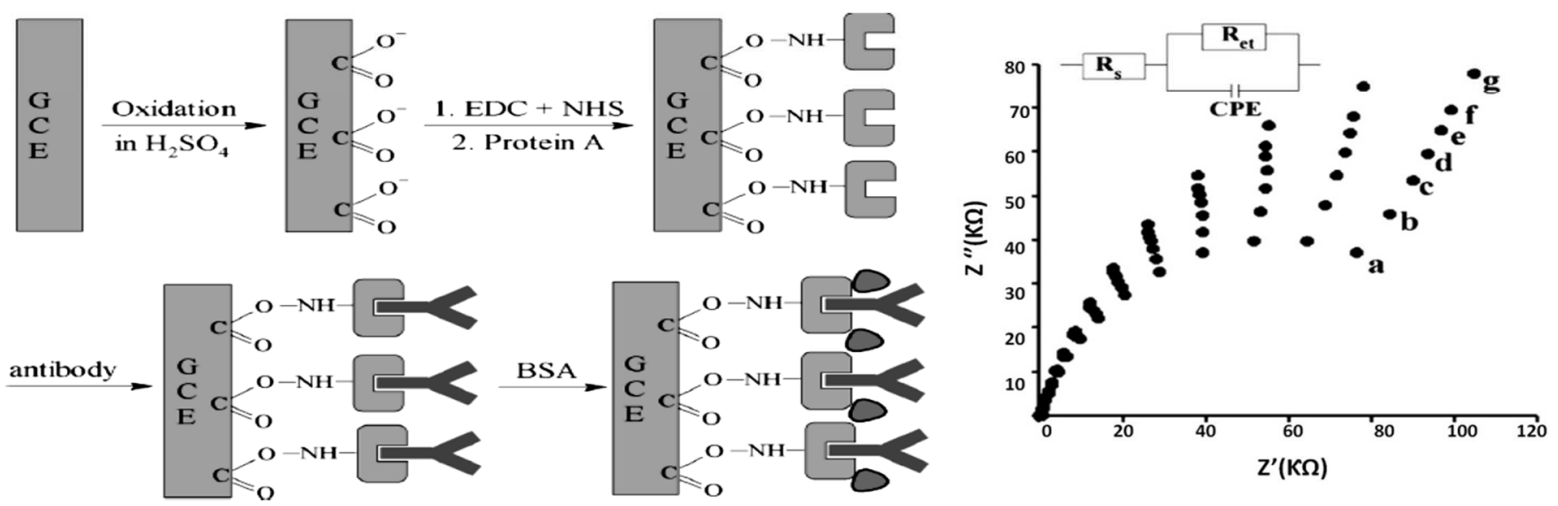

Fig. 4 (A) Example of electrochemical enzyme-linked immunoassay (ECEIA) sensor using gold nanoparticles as carriers of enzyme-labeled antibodies for signal amplification, applied for Pantoea stewartii sbusp. Stewartii (PSS) plant bacterial pathogen detection, together with the voltammetric signals obtained for PSS concentrations in the range of $2.0 \times 10^{7}-4.0 \times 10^{4}$ - cfu/ml. Adapted with permission from (Zhao et al. 2014). (B) Representative scheme of electrochemical spectroscopy impedance (EIS) immunosensor for Prunus necrotic ringspot virus (PNRV) DNA determination on glassy carbon electrodes together with the EIS spectra obtained for different dilutions of infected leaf extracts ranging: 100-0.01\%. Adapted with permission from (Jarocka et al. 2013). 
A

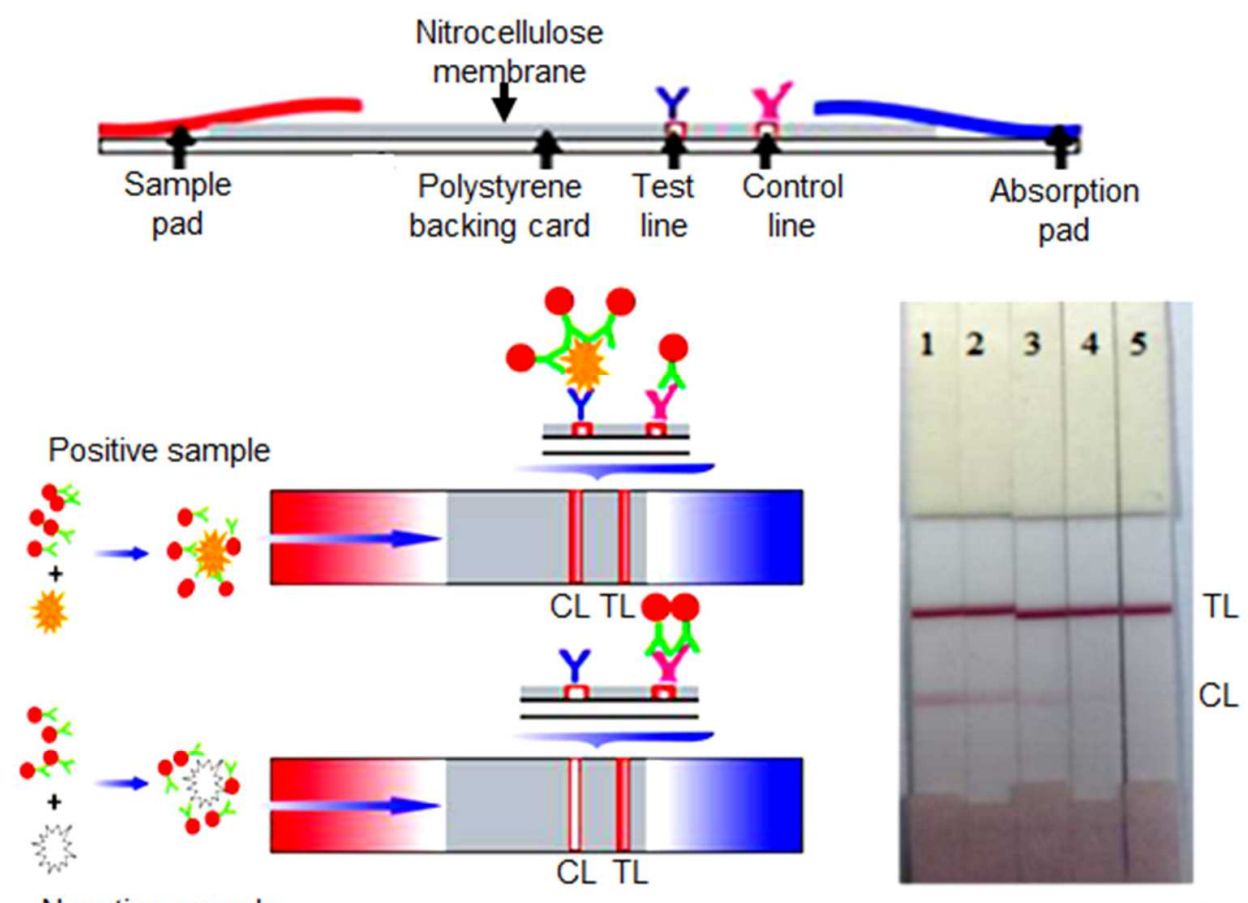

Negative sample

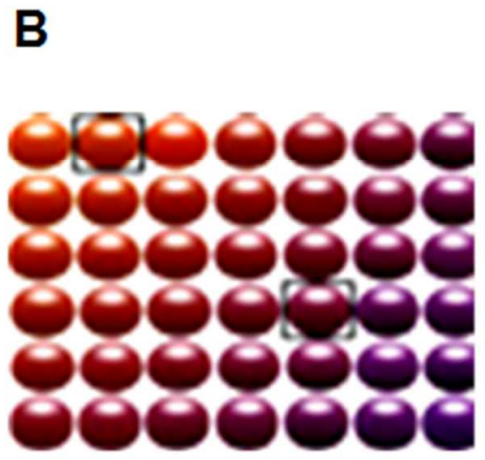

Magnetic microsphere

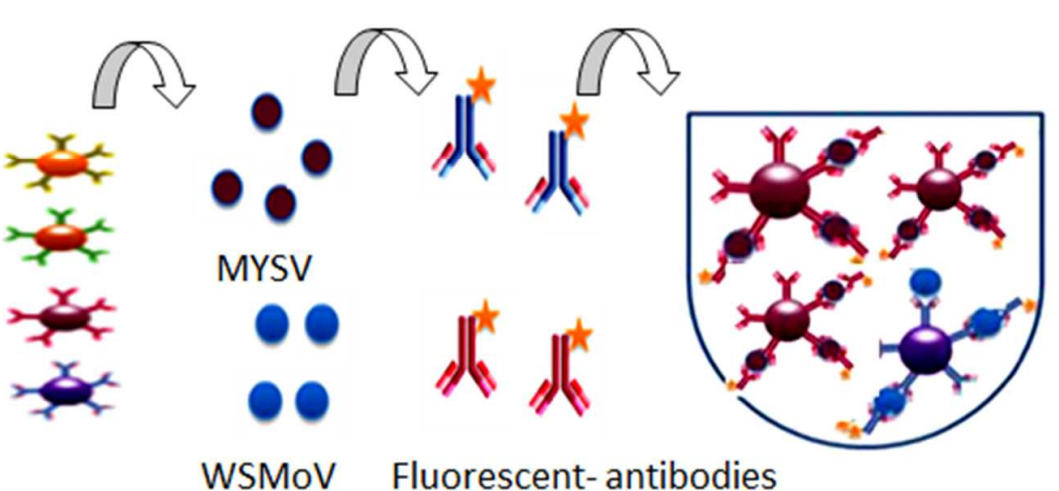

WSMoV Fluorescent-antibodies

Fig. 5 (A) Scheme of a lateral flow immunoassay (LFIA) based on gold nanoparticles designed for detection of Pantoea stewartii sbusp. Stewartii (PSS) plant pathogenic bacteria and pictures of the strips for pathogen concentrations from $1 \times 10^{7}$ to $1 \times 10^{5} \mathrm{cfu} / \mathrm{ml}$. Adapted with permission from (Feng et al. 2015). (B) Scheme of magnetic microsphere immunoassay for multidetection of Watermelon silver mottle virus (WSMoV) and Melon yellow spot virus (MYSV) plant viruses. Adapted with permission from (Charlermroj et al., 2013). 

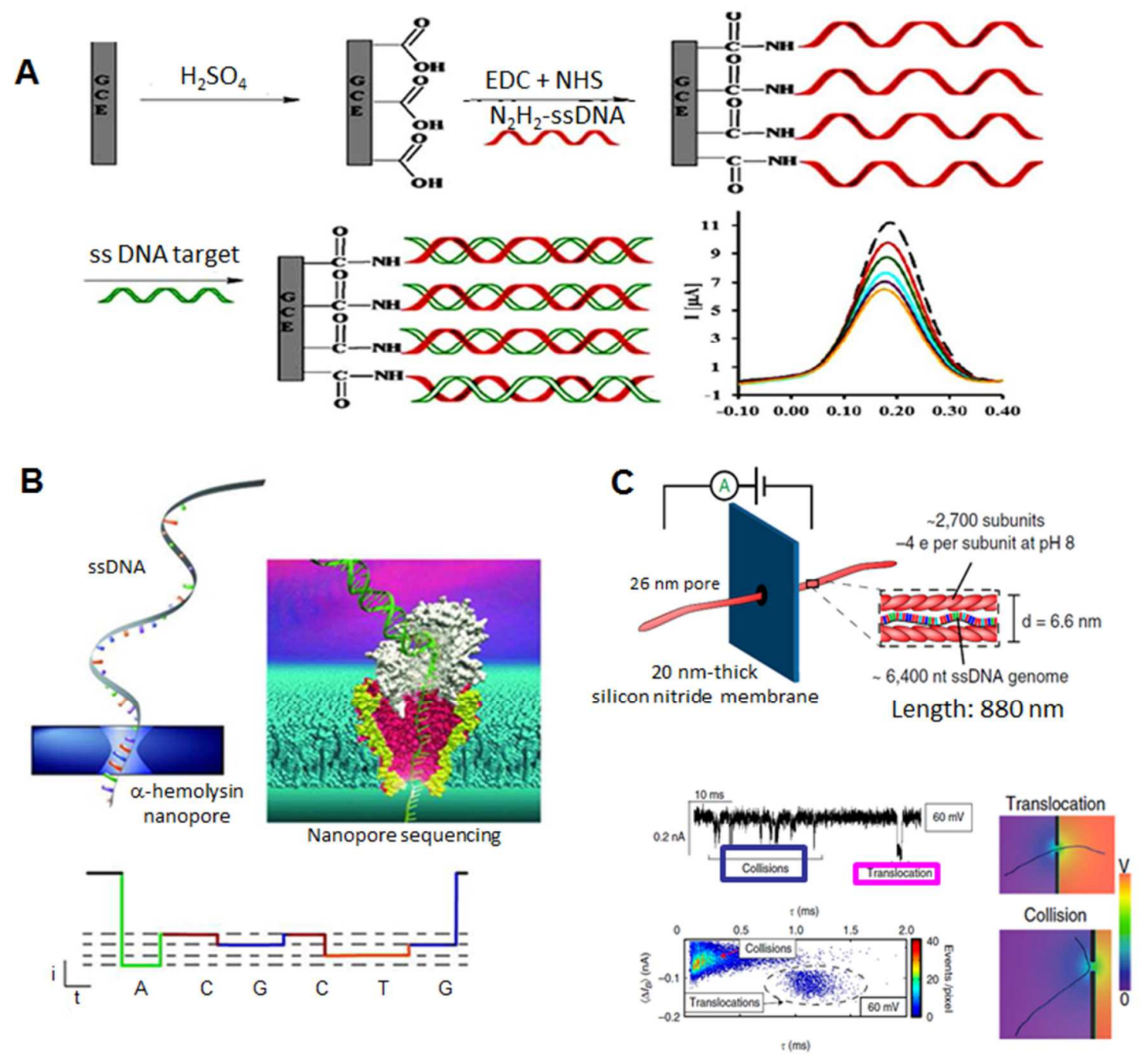

Fig. 6 (A) Example of label-free DNA hybridization approach based on voltammetric analysis applied for Plum pox virus (PPV) detection. Voltammetric signals correspond to 1-8 pM. Adapted with permission from (Malecka et al. 2014). (B) Scheme of the ssDNA translocation through a single $\alpha$-hemolysin pore and the associated electrical signatures as potential tool for pathogen DNA sequencing: each of the four bases produces characteristic time series recordings. Adapted from (Kasianowicz et al. 1996) with permission. (C) Illustration of a filamentous virus translocation through a single nanopore drilled on silicon nitride membranes (up) and its signatures discriminated from collisions (down) Adapted from (Mc Mullen et al. 2014) with permission.
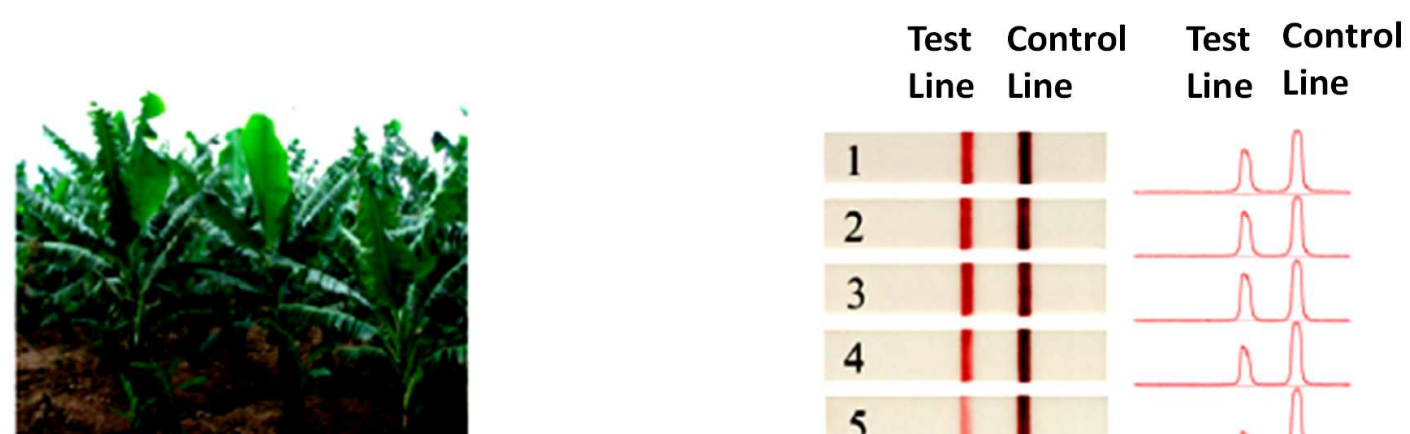
Fig.7 Lateral flow based on DNA hybridization using DNA probe labeled with AuNPs for Banana bunchy top virus (BBTV) detection, qualitative and semi quantitative measurements using different concentrations of BBTV (from $8 \times 10^{6}$ to $8 \times 10$ copy/ $\mu$ l) nucleic acid (right up) and a bar chart demonstrating its corresponding peak areas of the test line (right down).Adapted with permission from (Wei et al. 2015).

A

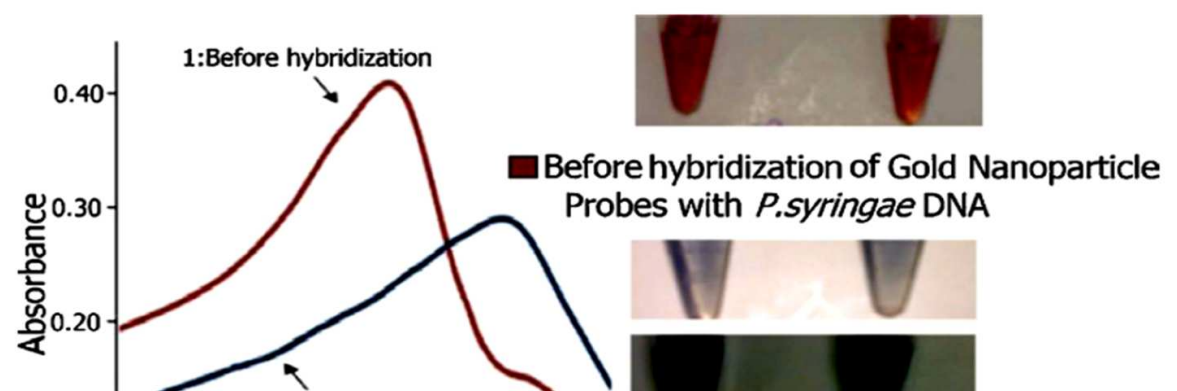


Fig. 8 (A) AuNPs aggregation for detection of DNA of Pesudomonas syringae, an important plant pathogenic bacterium with wide host plant range. Adapted with permission from (Vaseghi et al. 2013). (B) Scheme of a qualitative assay based on bridging flocculation of isothermally DNA amplicons (up) and its application in detecting phytopathogenic fungi Fusarium f.sp.conglutinans at different infection stages (down). Adapted with permission from (Wee et al. 2015). 
A PCR amplified sample

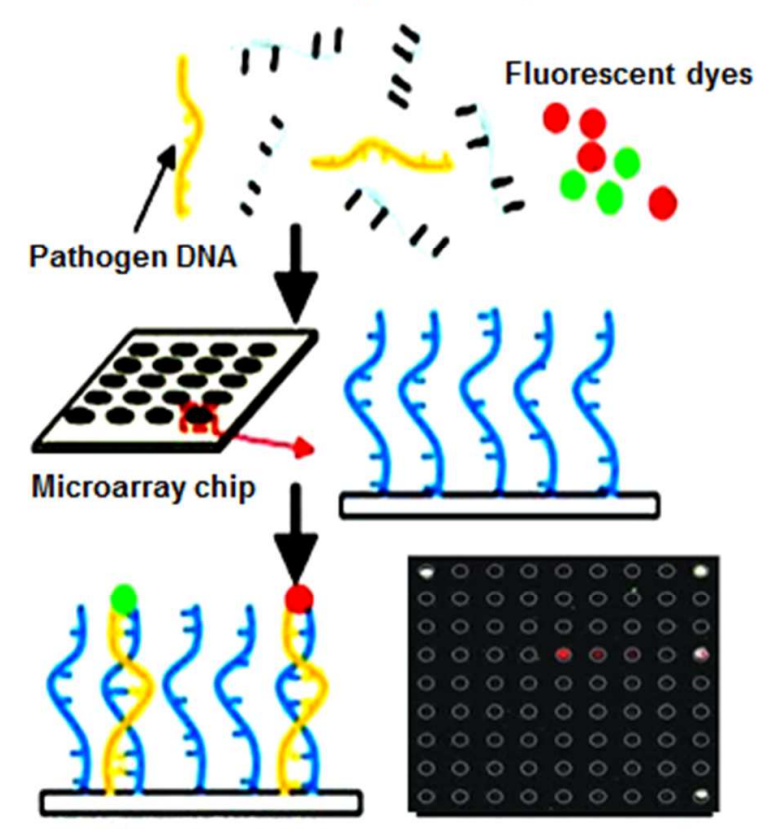

Hybridization of DNA Fluorescence measurement probe \& pathogen DNA
B

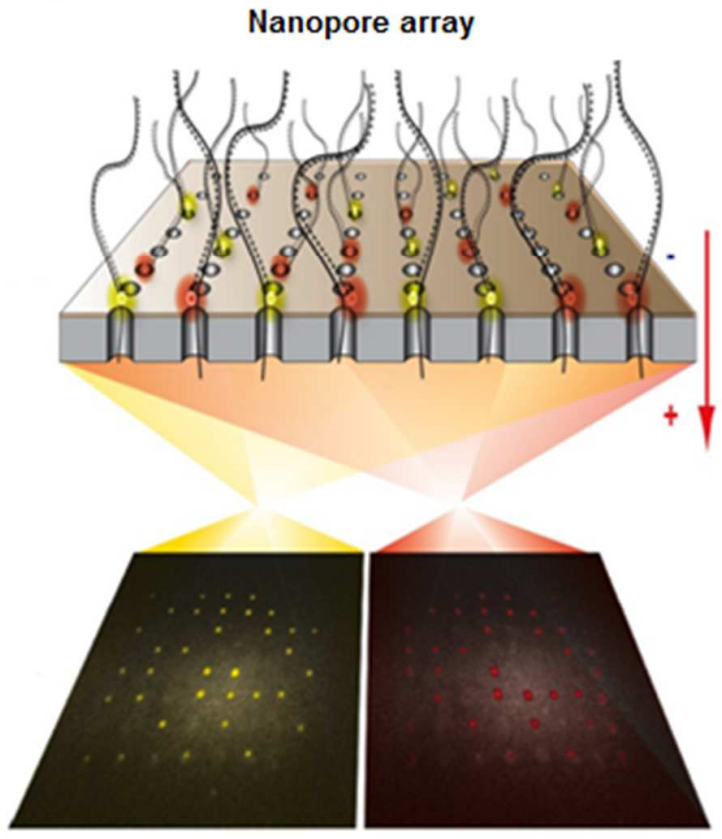

Fluorescence detection system

Fig.9 (A) Scheme of DNA microarray technique based on DNA hybridization for pathogen characterization applied for Broad bean wilt virus analysis. Red fluorescent pattern indicates to the presence of virus RNA. Adapted with permission from (Boonham et al. 2007; Nezhad, 2014). (B) Illustration of the promising optical platforms based on nanochannel arrays for optical detection of DNA. Adapted with permission from (McNally et al. 2010). 
A
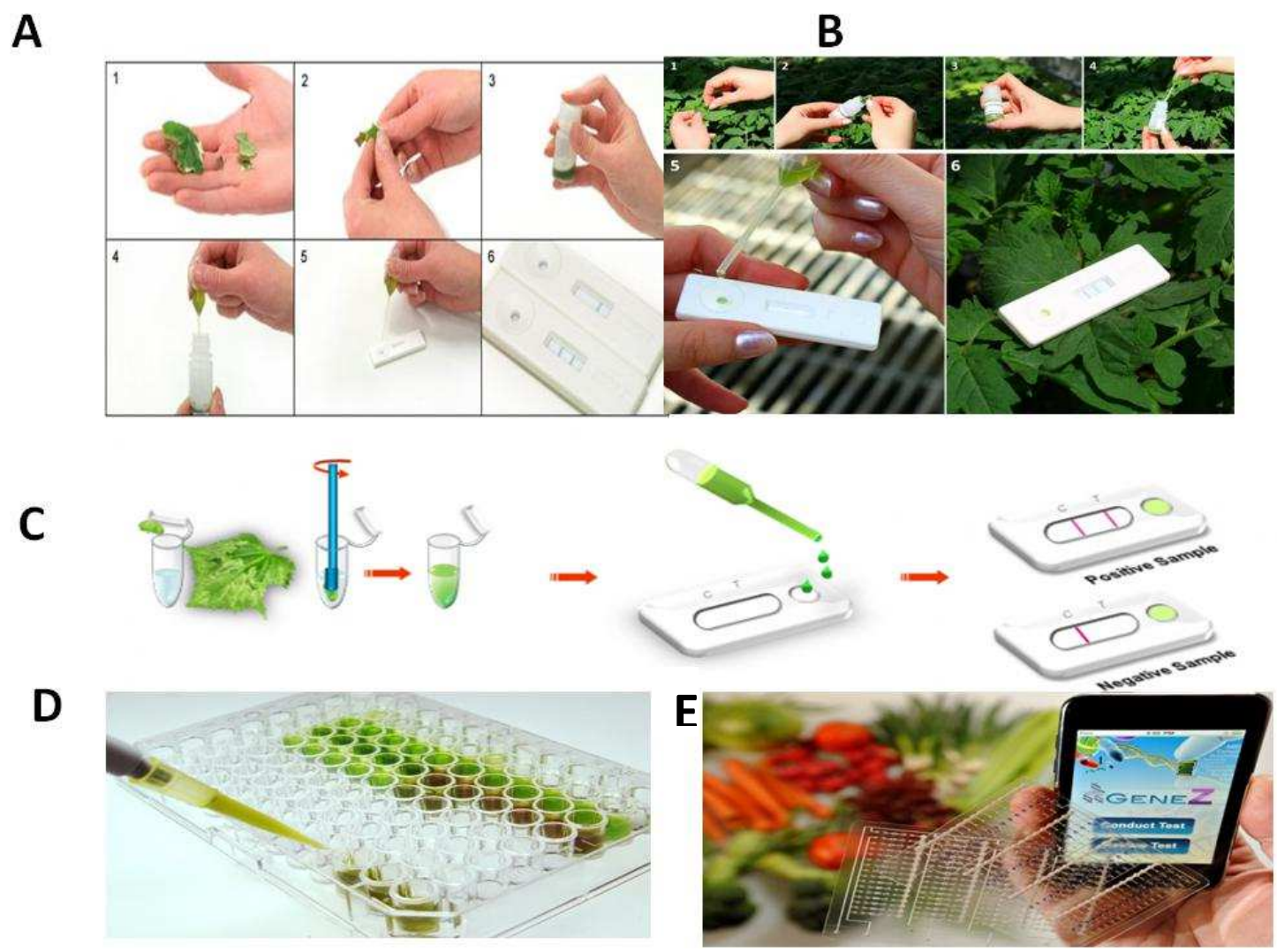

Fig. 10 Commercial devices for the detection of several plant diseases. (A-C) Lateral flow systems commercialized for phytophthora species, Erwinia amylovora and Potato virus $Y$ detection. Adapted with permission from (A) Ref. www.lachandra.com. (B) Ref. www.pocketdiagnostic.com. (C) Ref . www.loewe-info.com. (D) ELISA kit for the detection of Citrus tristeza virus, Acidovorax avenae ssp. citrulli and Botrytis cinerea. Adapted with permission from Ref. www.loewe-info.com. (E) Hybrid smart phone application and microfluidic to identify plant pathogen in minutes as promising device not yet applied on plant disease detection. Adapted with permission from Ref. www.treehugger.com. 